Discussion Paper No. 06-082

The Effect of Firm- and Industry-Level Contracts on Wages Evidence from Longitudinal Linked Employer-Employee Data

Nicole Gürtzgen

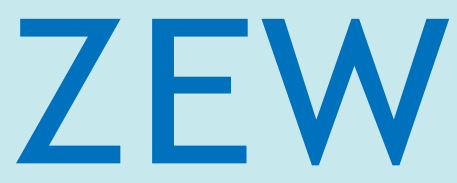

Zentrum für Europäische Wirtschaftsforschung $\mathrm{GmbH}$

Centre for European

Economic Research 
Discussion Paper No. 06-082

\title{
The Effect of Firm- and Industry-Level Contracts on Wages - Evidence from Longitudinal Linked Employer-Employee Data
}

\author{
Nicole Gürtzgen
}

Download this ZEW Discussion Paper from our ftp server:

ftp://ftp.zew.de/pub/zew-docs/dp/dp06082.pdf

Die Discussion Papers dienen einer möglichst schnellen Verbreitung von neueren Forschungsarbeiten des ZEW. Die Beiträge liegen in alleiniger Verantwortung der Autoren und stellen nicht notwendigerweise die Meinung des ZEW dar.

Discussion Papers are intended to make results of ZEW research promptly available to other economists in order to encourage discussion and suggestions for revisions. The authors are solely responsible for the contents which do not necessarily represent the opinion of the ZEW. 


\section{Non-technical summary:}

Using a large linked employer-employee data set, this paper presents new evidence on the collective bargaining wage effect in western and eastern Germany. The novel feature of our analysis is that we use a longitudinal data set. Thus, in contrast to previous studies, we seek to assess the extent to which differences in wages between workers in covered and uncovered firms really represent an effect of collective bargaining coverage, rather than a consequence of the non-random selection of workers and firms into the different regimes. The fact that we observe employers to change their contract status over time provides us with the opportunity to identify the impact on individual wages by measuring the relative wage gains or losses of workers employed in firms that change their contract status.

The results from a Pooled OLS specification indicate that differences in firm characteristics account for the largest proportion of omitted variable bias. Systematic sorting of observably better firms into the regimes appears to be more relevant for industry contracts in western Germany and for firm-level contracts in eastern Germany. The estimates from a fully interacted specification appear to support the hypothesis that unions compress some of the returns to observable worker attributes. However, the results from a fixed-effects specification show that a large part of this flattening of the wage structure arises from a selectivity bias, as workers with low levels of observable skills are positively and workers with higher levels of skills are negatively selected into covered firms. Wage decompositions indicate that the overall effect of collective bargaining coverage on the returns to observable attributes appears to be rather negligible once the selection into the regimes is accounted for.

Taken together, the fixed-effects specifications suggest the following conclusions. First, differences in observables and unobservables appear to explain the full firmlevel contract wage premium in western Germany and the full premium associated with industry-level contracts in eastern Germany. Second, there remains a small, but statistically significant wage premium of about 2 per cent for industry-level contracts in western Germany and a similar premium for firm-level contracts in eastern Germany. The result that selection into industry-level contracts appears to be somewhat more relevant in eastern Germany might be explained by the fact that the decision of joining or leaving an employers' association here is to a considerably larger extent left to the firm's discretion than in western Germany. In western Germany, membership in an employers' association is likely to be more exogenous, since it presumably reflects to a larger extent the result of a historically grown industrial relations structure. 


\title{
The Effect of Firm- and Industry-Level Contracts on Wages - Evidence from Longitudinal Linked Employer-Employee Data
}

\author{
Nicole Guertzgen \\ Centre for European Economic Research*
}

October 2006

\begin{abstract}
Using a large linked employer-employee data set, this paper presents new evidence on the collective bargaining wage effect in western and eastern Germany. The novel feature of our analysis is that we use a longitudinal data set. Thus, in contrast to previous studies, we seek to assess the extent to which differences in wages between workers in covered and uncovered firms really represent an effect of collective bargaining coverage, rather than a consequence of the non-random selection of workers and firms into the different regimes. By measuring the relative wage gains or losses of workers employed in firms that change contract status, we obtain estimates that depart considerably from previous results relying on cross-sectional data. Industry-level contracts in western Germany and firm-level contracts in eastern Germany are associated with a small, but statistically significant average wage premium of about 2 per cent. Moreover, wage decompositions indicate that the overall effect of collective bargaining coverage on the returns to observable attributes appears to be negligible once the selection into the regimes is accounted for.
\end{abstract}

Keywords: Union Wage Premium; Collective Bargaining Coverage

JEL-Code: J31; J51

\footnotetext{
${ }^{*}$ Centre for European Economic Research, Department of Labour Markets, Human Resources and Social Policy, L 7.1, 68161 Mannheim, Germany, E-Mail: Guertzgen@zew.de. I would like to thank Alisher Aldashev, Hendrik Jürges and Claus Schnabel for valuable comments and discussions. I also thank Holger Alda and Peter Jacobebbinghaus for help with the data at the Research Data Centre (FDZ) of the Federal Employment Services (BA) at the Institute for Employment Research (IAB), Nuremberg. The institutions mentioned are not responsible for the use of the data in this publication. Financial support from the German Research Foundation (DFG) under the Program "Potentials for more flexibility on heterogeneous labour markets" (Grant-No. PF 331/3-2) is gratefully acknowledged.
} 


\section{Introduction}

The question of whether unions are able to drive a wedge between the wages of comparable workers in the union and non-union sector is of considerable interest to an understanding of the wage determination process. While the empirical literature for the U.S and the U.K. has primarily focused on union membership as a determinant of individual wages (e.g. Blanchflower 1991, Card 1996, Andrews et al. 1998), in continental Europe it is rather collective bargaining coverage that matters. The reason is that extension mechanisms, which are widespread in European economies, can widen the coverage of collective bargaining agreements irrespective of individual workers' union membership status. Given the differences in institutional settings in which the bargaining may take place, a further question that has continued to motivate economic research is as to how firm-level contracts compare to industry-level contracts.

There is a large theoretical literature on the link between the bargaining structure and wages (Calmfors and Driffill 1988, Davidson 1988, Moene et al. 1993), whose predictions have been tested in a number of cross-country studies (Calmfors and Driffill 1988, Soskice 1990, OECD 1997, Calmfors 2001). More recently, with the increasing availability of linked employer-employee data, the relationship between collective bargaining coverage and wage outcomes has attracted renewed interest. By providing both information on wages at the individual level and collective bargaining coverage at the employers' level, such data permit to exploit intra-national variations in the bargaining structure to assess its impact on the level and structure of wages. Examples include Hartog et al. (2002) for the Netherlands, Cardoso and Portugal (2005) for Portugal, Stephan and Gerlach (2005) for Germany as well as Card and de la Rica (2006) for Spain. While Hartog et al. (2002) fail to detect any positive effect of bargaining coverage on wages, Stephan and Gerlach (2005) find industry and firm-level contracts raise the overall level of wages, with the wage mark-up being slightly larger under industry contracts. In contrast, the evidence by Cardoso and Portugal (2005) and Card and de la Rica (2006) points to higher wage premiums under firm-level contracts as compared to industry-level contracts.

Our paper presents new evidence on the collective bargaining wage effect, using a large-scale German Linked Employer-Employee data set. Our analysis of collective bargaining coverage and wages, which is the first comprehensive study for both western and eastern Germany, is motivated by several reasons. To begin with, and most importantly, previous evidence on the collective bargaining effect relies on crosssectional data and typically fails to address the selection problem. As has already 
been argued in the literature on union wage effects (Card 1996, Lemieux 2000), selection is likely to be a major issue, if collective bargaining contracts raise wages above the competitive wage and compress the returns to observable attributes. In this case, observed and unobserved productivity components are likely to be negatively correlated since, e.g., workers with low observed skills will only be hired if they exhibit high unobserved skills. In order to deal with such a potential selection bias, the evidence presented in this paper is based on a longitudinal data set. Hence, unlike the above cited studies, we seek to assess the extent to which differences in wages between workers in covered and uncovered firms really represent an effect of collective bargaining coverage, rather than a consequence of the non-random selection of workers (and firms) upon time-invariant unobservables into the different regimes. The fact that we observe employers to change their contract status over time provides us with the opportunity to identify the impact on individual wages by measuring the relative wage gains or losses of workers employed in firms that change their contract status. Clearly, such an identification strategy rules out the endogeneity of a change in contract status, since establishments changing contract status may experience different time-specific shocks than those that retain their contract status. To assess the severity of this problem, we separately analyse transitions from one regime to the other and compare the relative wage gain of individuals experiencing a change in contract status to different reference groups.

Secondly, the German case provides an instructive example for continental European extension mechanisms. Although negotiated wages apply strictly speaking only to union members, firms generally extend wage settlements to non-member employees as well. Moreover, central wage contracts may also apply to non-member firms if an agreement is declared to be generally binding. As a consequence, despite declining union membership among employees, which to date has reached a relatively modest level of roughly 20 per cent, collective bargaining coverage is still of crucial importance to the wage-setting process in Germany. For example, collective bargaining contracts in 2004 were estimated to cover about 41 per cent of employers and about 61 per cent of employees in western Germany (Addison et al. 2006).

A final, third, motivation is based on the fact that the institutional environment in Germany is characterised by the coexistence of different bargaining regimes. Collective bargaining contracts may take the form of either firm-level contracts or industry-level contracts. Moreover, in recent years wage determination without any bargaining coverage has become more important. This is particularly relevant for eastern Germany, where collective bargaining contracts are estimated to cover only 
19 per cent of employers in 2004 (Addison et al. 2006). Thus, with the increasing importance of the uncovered sector it becomes not only possible to compare wage outcomes under firm-level and industry-level contracts but also for workers in covered and uncovered firms.

The remainder of the paper proceeds as follows. Section 2 provides some institutional background information on German wage determination. Section 3 contains a theoretical discussion of how collective bargaining coverage may be expected to affect the level and the structure of wages. Section 4 presents the empirical analysis. Section 4.1. sets out the identification strategy for estimating the impact of collective bargaining on wage outcomes. While Section 4.2. provides a description of the data set used, Section 4.3. presents the estimation results. The final Section 5 concludes.

\section{Institutional Background}

In this section we provide some background on how collective bargaining affects German wage determination. Within the system of wage bargaining, regional and industry-wide collective wage agreements (Flächentarifverträge) rank among the most important contract type. Such centralised wage contracts are negotiated between an industry-specific trade union and an employers' association. While being legally binding on all member firms of the employers' association and on all employees who are members of the trade union, member firms generally extend the wage settlement to the non-member labour force as well. The reason is that nonmember employees who would receive a lower wage may be expected to join the union anyway in order to benefit from higher union wages. Moreover, central wage contracts may also apply to non-member firms and their employees if an agreement is declared to be generally binding by the Federal Ministry of Labour. Finally, there are voluntary extension mechanisms, i.e. firms without any legally binding agreement may voluntarily apply a central industry agreement. The predominance of industry-level wage bargaining along with the synchronisation of different collective agreements has led economists to characterise the German system of wage bargaining as medium-centralised with a high degree of coordination (Calmfors and Driffill 1988, Soskice 1990, OECD 2004).

Even though industry-level bargaining may be still be viewed as the predominant form of wage determination, in recent decades German industrial relations have witnessed a clear tendency towards alternative forms of wage determination. 
Evidence from the IAB-Establishment Panel indicates that the proportion of establishments with a legally binding industry-wide contract fell economy-wide from 48 per cent to 44 per cent over the time period 1996 to 2002 in western Germany, whereas the decline was from 28 per cent to 22 per cent in eastern Germany. ${ }^{1}$ This phenomenon is largely the result of a considerable drop in membership rates of employers' associations, with the decline being particularly pronounced among eastern German firms. ${ }^{2}$ After German unification the western German system of collective bargaining had been set up quite immediately by western unions in the East. The decline in membership rates in eastern Germany then arose primarily from a rapid wage convergence between western and eastern Germany which unions succeeded to achieve following German unification (Hunt 2001).

Employers leaving their employers' association either have the option of concluding a firm-specific contract with their respective industry union or becoming uncovered. However, at this point it is worthy to note that this decision is not necessarily left to the employer's discretion. For instance, even if a firm prefers to stay uncovered, its union may attempt to enforce a firm-specific contract. Whether such an attempt succeeds, ultimately depends on firm-specific union density. The underlying notion is that the union's ability to present the employer with a credible threat to strike may be expected to increase considerably with the proportion of workers who are organised in that union. ${ }^{3}$ Although the absolute number of firmspecific collective wage agreements has increased markedly since the beginning of the 1990s, this increase cannot explain the declining importance of industry-level contracts. Evidence from the IAB-Establishment Panel indicates that the share of establishments reporting the existence of a firm-level contract fell from 10.2 to 2.4 per cent in western Germany over the time period 1996 to 2002, and from 14.9 to 4.2 per cent in eastern Germany. ${ }^{4}$ Thus, the decline in industry-level coverage rather resulted in an increasing share of uncovered establishments. In uncovered firms wage determination may either take the form of individual wage contracts or of plant-specific agreements (Betriebsvereinbarungen) between works councils and

\footnotetext{
${ }^{1}$ Own calculations based on IAB-Establishment Panel.

${ }^{2}$ For example, the employers' association "Gesamtmetall" reports that the share of employees at member firms as a percentage of total employment in the metal and electrical industry fell in West Germany from 77.4 per cent to 57.6 per cent over the time period 1984 to 2004, and in East Germany from 66 per cent in 1991 to 18.1 per cent in 2004 (Gesamtmetall 2006).

${ }^{3}$ Indirect evidence for this is provided by Fitzenberger et al. (2006). Using a cross-section from the German Salary and Wage Structure Survey the authors find the effect of firm-specific collective bargaining coverage increase with the aggregate propensity of union membership.

${ }^{4}$ Own calculations based on IAB-Establishment Panel. It should be noted here that part of the decline in firm-level coverage might have been caused by a change in the survey question concerning firm-level contracts (see e.g. Schnabel et al. (2006)). See also Section 4.3.4. and Footnote 17.
} 
the management. Even though German legislation prohibits works councils from negotiating about issues that are normally dealt with in collective agreements, they are widely recognised to play a crucial role in wage determination (see e.g. Hassel 1999, Hübler and Jirjahn 2003). Particularly in those uncovered firms who informally follow the terms of a central industry agreement, works councils are likely to be involved in the implementation of voluntarily applied contract terms.

Summing up, the coexistence of different bargaining regimes in Germany provides an environment that is suitable for estimating (1) how industry-level and firm-level coverage affects wages relative to no-coverage and (2) for assessing the relative effect of firm-level versus industry-level contracts.

\section{Theoretical Considerations}

In an institutional environment, such as the German one, the effect of collective bargaining coverage on the level of wages is a-priori ambiguous. Standard bargaining theory generally predicts covered firms to pay higher wages relative to uncovered firms (e.g. Oswald 1982). The underlying notion is that unions may be expected to have greater bargaining power than works councils or individual workers in uncovered firms. A further explanation for why collective bargaining coverage might lead to higher wage outcomes relates to the relatively centralised union structure in Germany. In their seminal paper, Calmfors and Driffill (1988) argue that with more centralised wage bargaining unions are able to secure higher wages, since they internalise positive externalities arising from demand spill-over effects across firms (or industries) producing substitutable goods. However, the authors also note that with more centralised bargaining unions progressively take into account negative externalities since the impact of the negotiated wage on the general consumption price-level becomes larger as centralisation increases. These two countervailing effects give rise to the well-known "hump-shaped" relationship between wages and the degree of bargaining centralisation. The question of whether collective bargaining coverage produces higher wage outcomes relative to uncovered firms therefore depends crucially on the relative extent to which positive and negative externalities are internalised by German industry unions. It is important to note that the internalisation of externalities may also be relevant under firm-specific contracts, because such contracts are typically concluded by industry unions.

Collective bargaining is not only believed to affect the level but also the struc-

ture of wages. There is widespread evidence that collective wage contracts appear 
to standardise wages across firms and across skill groups (see e.g. Cardoso and Portugal 2005, Stephan and Gerlach 2005). A frequently invoked theoretical explanation refers to the insurance motive, which asserts that unions may favour a compressed wage structure due to workers' demand for income insurance (e.g. Agell and Lommerud 1992, Burda 1995). The fact that collective contracts may affect the returns to observed attributes has important consequences for the selection of workers and firms into bargaining coverage. If, for example, collective contracts compress the returns to observed skills, jobs in covered firms are particularly desirable for those workers with low observed skills and less attractive for those with high observed skills. A simple queuing model then predicts employers to hire the most productive workers from those with low observed skills. Workers with high observed skills, in contrast, should be negatively selected as a job in a covered firm will be desirable only for those with low unobserved skills (see Farber 1983, Card 1996, Lemieux 2000). It should be noted here that the term "unobserved" refers to worker skills that are observable to employers, but not observed by the researcher. As a result, taking into account the selection upon unobservables should reduce a potential wage premium among low-skilled workers to a larger extent than among high-skilled workers.

A similar selection process may take place with respect to employers' characteristics. For Germany, recent evidence suggests that collective wage agreements appear to suppress firm wage differentials arising from different profitability conditions (Guertzgen 2005). Given that such contracts shelter firms against excessive rent-sharing at the firm-level, the selection into collective bargaining coverage is thus particularly desirable for highly profitable firms. As firm-specific profitability is likely to be correlated with other unobservable firm characteristics associated with higher wages, accounting for such a selection process would also lead to a decline in a potential contract wage premium. Selection of better firms into bargaining coverage may not only occur on the employer's, but also on the union's side. For the U.S., DiNardo and Lee (2004) argue that one potential source of selectivity bias may be based on the fact that unions may find it particularly profitable to organise at highly successful firms. The same phenomenon may occur in an institutional setting, such as the German one, where unions may enforce firm-level agreements with employers not being members of an employers' association. As long as unions find it beneficial to enforce such contracts at systematically better firms, this may also give rise to a potential selectivity bias. 


\section{Empirical Analysis}

\subsection{Estimation Strategy}

To quantify the collective bargaining wage premiums, we consider a wage equation taking the following form:

$$
\ln w_{i t}=\mu+\gamma_{C} \cdot C_{j t}+\gamma_{F} \cdot F_{j t}+\beta \cdot x_{i t}^{\prime}+\delta \cdot u_{i}^{\prime}+\eta \cdot w_{j t}^{\prime}+\rho \cdot q_{j}^{\prime}+\nu_{i j t}
$$

where the error component may be written as

$$
\nu_{i j t}=\alpha_{i}+\phi_{j}+\epsilon_{i j t}
$$

There are $i=1, \ldots, N$ individuals, and $N^{*}=\sum T_{i}$ total worker-year observations. Since we will use matched worker-establishment data, $j$ refers to the establishment which employs individual $i$ at time $t$, i.e. we have strictly speaking $j=j(i, t)$, with $j=1, \ldots, J$. The dependent variable, $\ln w_{i t}$, is the individual log daily wage. The explanatory variables of main interest are $C_{j t}$ and $F_{j t}$, which are indicator variables taking on the value of unity if the establishment that employs individual $i$ at time $t$ is subject to a centralised industry-level or a firm-level contract. $x_{i t}^{\prime}$ represents a vector of time-varying individual covariates with a coefficient vector $\beta$, while $u_{i}^{\prime}$ denotes a vector of individual time-constant characteristics with a coefficient vector $\delta$. Similarly, $w_{j t}^{\prime}$ and $q_{j}^{\prime}$ represent time-varying and time-constant $j$-level covariates with coefficient vectors $\eta$ and $\rho$. Time dummies are included to capture common macroeconomic effects. Finally, in eq. (2) the unobserved component comprises an individual unobserved effect, $\alpha_{i}$, establishment-specific unobserved heterogeneity, $\phi_{j}$, and a time-specific error term, $\epsilon_{i j t}$.

In our estimation strategy, we first focus on a simple pooled Ordinary Least Squares (POLS) specification of eq. (1), in which neither $\alpha_{i}$ nor $\phi_{j}$ are controlled for. The POLS estimations serve as a benchmark case and will be modified in various respects: First, to assess the impact of collective bargaining coverage on the overall wage structure, we will estimate a fully interacted model, which includes interaction terms of all covariates with the contract status dummies. The interacted regressors are expressed in terms of deviations from their sample means, allowing us to interpret the estimated coefficient on firm-level and centralised contracts as the wage premium for a worker with the average characteristics of the full sample. 
Hence, eq. (1) changes to:

$$
\begin{aligned}
\ln w_{i t} & =\mu+\gamma_{C} \cdot C_{j t}+\gamma_{F} \cdot F_{j t}+\beta \cdot x_{i t}^{\prime}+\eta \cdot w_{j t}^{\prime}+\delta \cdot u_{i}^{\prime}+\rho \cdot q_{j}^{\prime} \\
& \beta_{C} \cdot C_{j t} \cdot\left(x_{i t}^{\prime}-\bar{x}\right)+\delta_{C} \cdot C_{j t} \cdot\left(u_{i}^{\prime}-\bar{u}\right)+ \\
& \eta_{C} \cdot C_{j t} \cdot\left(w_{j t}^{\prime}-\bar{w}\right)+\rho_{C} \cdot C_{j t} \cdot\left(q_{j}^{\prime}-\bar{q}\right)+ \\
& \beta_{F} \cdot F_{j t} \cdot\left(x_{i t}^{\prime}-\bar{x}\right)+\delta_{F} \cdot F_{j t} \cdot\left(u_{i}^{\prime}-\bar{u}\right)+ \\
& \eta_{F} \cdot F_{j t} \cdot\left(w_{j t}^{\prime}-\bar{w}\right)+\rho_{F} \cdot F_{j t} \cdot\left(q_{j}^{\prime}-\bar{q}\right)+\alpha_{i}+\phi_{j}+\epsilon_{i j t}
\end{aligned}
$$

Second, to assess the extent to which sorting based upon unobservable characteristics of workers and firms affects our estimates, we will present estimates of a fixed-effects specification which eliminates $\alpha_{i}$ as well as $\phi_{j}$. To remove $\alpha_{i}+\phi_{j}$, we firstdifference eq. (1) within each individual-establishment combination, also referred to as individual-establishment-'spells' (Andrews et al. 2005). Defining $\theta_{s}=\alpha_{i}+\phi_{j}$ in eq. (1) as the unobserved spell-level effect for spell $s$, first-differencing of eq. (1) yields:

$$
\Delta \ln w_{i t}=\gamma_{C} \cdot \Delta C_{j t}+\gamma_{F} \cdot \Delta F_{j t}+\beta \cdot \Delta x_{i t}^{\prime}+\eta \cdot \Delta w_{j t}^{\prime}+\Delta \epsilon_{i j t},
$$

where first-differencing within each spell sweeps out $\theta_{s}$. Thus, the coefficients on $\Delta C_{j t}$ and $\Delta F_{j t}$ will yield a consistent estimator of the wage premiums as long as $\Delta C_{j t}$ and $\Delta F_{j t}$ are uncorrelated with $\Delta \epsilon_{i j t}$. Correspondingly, the interacted specification reads as

$\Delta \ln w_{i t}=\gamma_{C} \cdot \Delta C_{j t}+\gamma_{F} \cdot \Delta F_{j t}+\beta \cdot \Delta x_{i t}^{\prime}+\eta \cdot \Delta w_{j t}^{\prime}+$

$$
\begin{aligned}
& \beta_{C} \cdot\left(C_{j t}\left(x_{i t}^{\prime}-\bar{x}\right)-C_{j t-1}\left(x_{i t-1}^{\prime}-\bar{x}\right)\right)+\delta_{C} \cdot \Delta C_{j t}\left(u_{i}^{\prime}-\bar{u}\right)+ \\
& \eta_{C} \cdot\left(C_{j t}\left(w_{j t}^{\prime}-\bar{w}\right)-C_{j t-1}\left(w_{j t-1}^{\prime}-\bar{w}\right)\right)+\rho_{C} \cdot \Delta C_{j t}\left(q_{j}^{\prime}-\bar{q}\right)+ \\
& \beta_{F} \cdot\left(F_{j t}\left(x_{i t}^{\prime}-\bar{x}\right)-F_{j t-1}\left(x_{i t-1}^{\prime}-\bar{x}\right)\right)+\delta_{F} \cdot \Delta F_{j t}\left(u_{i}^{\prime}-\bar{u}\right)+ \\
& \eta_{F} \cdot\left(F_{j t}\left(w_{j t}^{\prime}-\bar{w}\right)-F_{j t-1}\left(w_{j t-1}^{\prime}-\bar{w}\right)\right)+\rho_{F} \cdot \Delta F_{j t}\left(q_{j}^{\prime}-\bar{q}\right)+\Delta \epsilon_{i j t} .
\end{aligned}
$$

From eq. (3) it becomes clear that spell first-differencing eliminates time-constant individual characteristics $u_{i}^{\prime}$ as well as time-constant establishment variables $q_{j}^{\prime}$, so that the coefficient vectors $\delta$ and $\rho$ cannot be identified. Only the interaction coefficients $\delta_{r}, \rho_{r}, r=C, F$, are identified from variations in contract status, i.e. unless $\Delta C_{j t} \neq 0$ and $\Delta F_{j t} \neq 0$. For this reason, it is common to subsume observable timeconstant and unobservable attributes into one single individual- and establishment effect, i.e. $\varphi_{i}=\delta \cdot u_{i}+\alpha_{i}$ as well as $\vartheta_{j}=\rho \cdot q_{j}+\phi_{j}$.

Finally, eq. (3) clarifies that our identification strategy relies on the assumption that a change in contract status is uncorrelated with time-specific unobservables. 
This assumption rules out, for example, that establishments changing contract status experience different time-specific shocks than those that retain their contract status. Clearly, it is easy to imagine situations in which this assumption will be violated. On the employer's side, for example, leaving collective bargaining might be systematically correlated with negative shocks. On the union's side, however, enforcing a firm-level contract might be correlated with positive shocks if unions are more likely to do so in better times. In such a case, identification of the contract wage premium requires instrumental variables that affect contract status but not wages. Unfortunately, it is hard to think of any variables satisfying these requirements. However, we attempt to assess the severity and direction of a potential endogeneity bias. To do so, we separately analyse transitions from one regime to the other and subsequently compare the wage gain of individuals experiencing a change in contract status to the wage gain of two different comparison groups. The first one comprises those individuals that stay in the origin regime, while the second one consists of those always being covered by the destination regime. As far as differences in unobservables are likely to be correlated with differences in observables, a comparison of observable characteristics of switching plants and those in the respective comparison groups then may give us some further indication about a direction of a potential endogeneity bias.

\subsection{Data and Variable Description}

In the empirical analysis we use data from the IAB Linked Employer-Employee panel (LIAB) which combines data from the IAB-Establishment Panel and the Employment Statistics Register. The IAB-Establishment Panel is based on an annual survey of establishments in western Germany administered since 1993 by the research institute of the Federal Employment Services in Nuremberg. Establishments in eastern Germany entered the panel in 1996. The database is a representative sample of German establishments employing at least one employee who pays social security contributions. The survey collects numerous information on establishment structure and performance, as e.g. sales, the share of materials in sales and investment expenditures (see e.g. Bellmann et al. 2002). Most importantly, establishments are asked to report whether they are bound to an industry-wide collective wage agreement or, alternatively, to a firm-specific wage agreement. Moreover, since 1999 those establishments without any binding collective contract are asked whether they follow informally the terms of an industry-wide agreement. However, for the available waves respondents are not asked to provide any information on the precise nature 
of the voluntarily applied contract terms. As a result, the informational content of this question remains rather elusive. Throughout the following analysis, collective bargaining status therefore refers to the existence of a legally binding agreement, i.e. establishments informally following the terms of an industry agreement will be treated as being uncovered. As a consequence, our estimated wage premiums need to be interpreted as wage mark-ups associated with a legally binding collective wage agreement.

The worker information comes from the Employment Statistics Register, which is an administrative panel data set of all employees paying social security contributions (see e.g. Bender et al. 2000). The data are based on notifications which employers are obliged to provide for each employee covered by the German social security system. Those notifications are required whenever an employment relationship begins or ends. In addition, there is at least one annual compulsory notification for all employees who are employed on the $31^{\text {st }}$ December of each year. Due to its administrative nature, this database has the advantage of providing reliable information on daily earnings that are subject to social security contributions. The establishment and worker data sets contain a unique establishment identification number. This allows us to match information on all employees covered by the social security system with the establishments in the IAB-Establishment Panel.

The construction of the Linked Employer-Employee data set occurs in two steps: First, we select establishments from the establishment panel data set. From the available waves 1993 to 2002, we use the years 1995 to 2002, since detailed information on bargaining coverage is available only from 1995 onwards. Since information on a number of variables, as e.g. investment expenditures and sales are gathered retrospectively for the preceding year, we lose information on the last year. Moreover, we restrict our sample to establishments from the mining and manufacturing sector with at least two employees. We focus on these sectors for two reasons: First, unions are generally believed to be particularly strong in this part of the economy (Hassel 1999, Addison et al. 2006) and second, former studies have already established significant wage premiums associated with collective bargaining contracts in these sectors (Stephan and Gerlach 2005). In order to be able to conduct firstdifferencing, only establishments with consistent information on the variables of interest (described below) and at least two consecutive time series observations are included in our sample. To avoid measuring spurious changes in contract status, we exclude from the remaining establishments $(2,156)$ those that change their col- 
lective bargaining status more than once in the time-period under consideration. ${ }^{5}$ This results in a sample of 2,014 establishments with 6,086 observations, yielding an unbalanced panel containing establishment observations with, on average, 3.02 years of data.

In the second step, we merge the establishment data with notifications for all employees who are employed by the selected establishments on June $30^{\text {th }}$ of each year. From the worker data we drop observations for apprentices, part-time workers and homeworkers. ${ }^{6}$ To avoid modeling human capital formation and retirement decisions, we exclude individuals younger than 19 and older than 55. Moreover, since we consider only full-time workers, we eliminate those whose wage falls short of some threshold level. ${ }^{7}$ Again, we consider only those individuals for whom at least two consecutive time series observations are available. The final sample comprises 512,507 individuals in 1,909 establishments, yielding an unbalanced panel containing 1,752,212 individual observations with, on average, 3.42 years of data for each worker. $^{8}$

The individual data include information on the gross daily wage, age, gender, nationality, employment status (blue/white-collar), educational status (six categories) ${ }^{9}$ and on the date of entry into the establishment. The latter is used to approximate tenure by subtracting the entry date from the ending date of the employer's notification which is available from the worker data. Note, however, that this proxy does not account for potential employment interruptions which might have occurred during this time span.

The dependent variable in the subsequent analysis is the real gross daily wage. The wage is reported inclusive of fringe-benefits as long as such wage supplements are subject to social security contributions. Since there is an upper contribution limit to the social security system, gross daily wages are top-coded. In our sample, top-coding affects 12.5 per cent of all observations. To address this problem,

\footnotetext{
${ }^{5} 142$ establishments out of 463 establishments that exhibit a variation in contract status change their bargaining status more than once.

${ }^{6}$ Part-time workers are excluded because the Employment Statistics Register lacks explicit information on hours worked.

${ }^{7}$ The threshold level is defined as the twice amount of the lower social security contribution limit.

${ }^{8}$ Note that the exclusion of certain individual groups entails a loss of 105 establishments.

${ }^{9}$ The categories are: No degree, vocational training degree, highschool degree (Abitur), highschool degree and vocational training, technical college degree and university degree. Missing and inconsistent data on education are corrected according to the imputation procedure described in Fitzenberger et al. (2005). This procedure relies, roughly speaking, on the assumption that individuals cannot lose their educational degrees.
} 
we construct 42 cells based on education, gender and year. For each cell, a tobit regression is estimated with log daily wages as the dependent variable and individual and establishment covariates as explanatory variables (see Table 1 below). As described in Gartner (2005), right-censored observations are replaced by wages randomly drawn from a truncated normal distribution whose moments are constructed by the predicted values from the Tobit regressions and whose (lower) truncation point is given by the contribution limit to the social security system. After this imputation procedure, nominal wages are deflated by the Consumer Price Index of the Federal Statistical Office Germany normalised to 1 in 2000. Turning to the establishment variables, we control for establishment size, per-capita quasi-rents, the capital-labour ratio, the existence of a works council as well as industry-specific and firm-specific collective bargaining coverage. Table A1 in the appendix provides a more detailed description of the construction of the establishment variables.

Table 1 presents summary statistics for the variables used in the subsequent analysis. The first two columns report statistics averaged over individuals, whereas the last two columns present statistics that are averaged over establishments. Due to the underlying distribution of establishment size, both statistics partly differ substantially from each other. Because larger establishments pay on average higher wages and are more profitable in terms of per-capita quasi-rents, the underlying sample means are lower on the establishment level. Moreover, there are also considerable differences with respect to collective bargaining coverage. Large establishments are much more likely to be covered by an industry-wide agreement, whereas small establishments are more likely to belong to the non-union sector, which is line with what has been found earlier in the literature (e.g. Schnabel et al. 2006). As a result, the majority of individuals (84 per cent) are employed by an establishment that adopts an industry-wide agreement. The fraction of individuals covered by a firm-specific agreement amounts to 10 per cent. Finally, only 6 per cent of all individuals are subject to no agreement at all, even though the fraction of uncovered establishments amounts to about 38 per cent.

The left panel of Table A2 in the appendix reports sample statistics for individuals subject to an industry-level contract, a firm-level contract and for those without any bargaining coverage for the western German sample. The corresponding statistics for the eastern German sample are presented in the right panel of Table A2. In the western German sample, firm-level contracts are associated with the largest raw wage differential and the lowest variability in wages. The sample means for the establishment variables reveal that workers subject to firm-level agreements are, on 
Table 1: Summary statistics

\begin{tabular}{|c|c|c|c|c|c|}
\hline \multirow[t]{2}{*}{ Variable } & \multirow[t]{2}{*}{ Definition } & Mean & Std.-Dev. & Mean & Std.-Dev. \\
\hline & & \multicolumn{2}{|c|}{ Individual level } & \multicolumn{2}{|c|}{ Establishm. level } \\
\hline \multicolumn{6}{|c|}{ INDIVIDUAL CHARACTERISTICS } \\
\hline LOG WAGE & Log real daily wage in DM & 5.23 & 0.33 & 4.92 & 0.34 \\
\hline FEMALE & Female worker & 0.19 & -- & 0.25 & - \\
\hline AGE & Age in years & 39.18 & 8.83 & 39.01 & 3.94 \\
\hline TENURE & Tenure in months & 130.85 & 86.74 & 94.96 & 49.04 \\
\hline FOREIGN & Foreign worker & 0.10 & -- & 0.05 & -- \\
\hline WHITECOLL & White-collar worker & 0.37 & -- & 0.32 & - \\
\hline VOCATIO & Vocational degree & 0.68 & -- & 0.77 & - \\
\hline HIGHSCHOOL & Highschool degree & $4.9 e^{-03}$ & - & $3.2 e^{-03}$ & - \\
\hline VOC-HIGH & Voc. and Highschool degree & 0.03 & - & 0.03 & - \\
\hline TECHN-UNI & Technical Univ. degree & 0.06 & -- & 0.04 & - \\
\hline UNI & University degree & 0.06 & - & 0.04 & -- \\
\hline \multicolumn{6}{|c|}{ ESTABLISHMENT CHARACTERISTICS } \\
\hline QUASI-RENT & Per-capita quasi-rent & 1.12 & 0.90 & 0.63 & 0.83 \\
\hline SIZE & Establishment size & $5,229.50$ & $10,368.76$ & 380.45 & $1,465.38$ \\
\hline CENT & Industry-level contract & 0.84 & - & 0.53 & - \\
\hline FIRM & Firm-level contract & 0.10 & - & 0.09 & - \\
\hline WCOUNCIL & Works council & 0.96 & - & 0.54 & - \\
\hline $\mathrm{K} / \mathrm{L}$ & Capital-labour ratio & 1.78 & 3.50 & 1.75 & 8.18 \\
\hline EAST & Eastern Germany & 0.15 & -- & 0.45 & - \\
\hline Individuals & & &, 507 & & \\
\hline Establishments & & & & & 1,909 \\
\hline
\end{tabular}

Source: LIAB 1995-2002.

Note: 1,909 establishments, 512,507 individuals, 1,752,212 observations. Per-capita quasirents and the capital-labour ratio are measured in 100,000 DM. $1 €$ corresponds to 1.95583 DM. 
average, employed by more capital-intensive and more profitable firms, followed by those covered by an industry-wide agreement. As to the individual characteristics, workers under firm- or industry-specific contracts are, on average, more likely to be male, are less likely to have no educational degree and have more months of (potential) tenure relative to uncovered individuals. Finally, uncovered individuals are more likely to be white-collar workers. A somewhat different pattern is found for the eastern German sample. Here, the largest raw wage differential and the lowest variability in wages emerges under centralised contracts. Table A2 shows that workers under centralised agreements are, on average, employed by larger and more profitable firms, followed by those subject to a firm-level agreement. Finally, workers under centralised contracts are more likely to be male, white-collar, and have more months of potential tenure relative to uncovered individuals and those subject to firm contracts. As a result, for both the western and eastern German sample, most of the differences in observed establishment and individual characteristics would generally predict higher wages for workers in covered establishments, which clearly requires a multivariate estimation strategy.

\subsection{Results}

\subsubsection{Pooled OLS Results}

The left panel of Table 2 reports the results from the pooled OLS (POLS) regression using the western German sample. Model (1) indicates that the raw wage differential amounts to 16 per cent under industry contracts and to 20.6 per cent under firmlevel contracts. Adding individual characteristics increases the explanatory power of the model considerably and reduces the coefficients to 0.116 and 0.155 , suggesting that about one quarter of the correlation between collective bargaining coverage and wages is due to systematic sorting of workers across firms (Model (2)). Including establishment characteristics, such as establishment size, the capital-labour ratio, per-capita quasi-rents and the existence of a works council leads to a further substantial decrease in the coefficients and renders them insignificant. The estimated wage premium of industry contracts decreases by 80 per cent, while the mark-up of firm-level contracts drops by 70 per cent. 


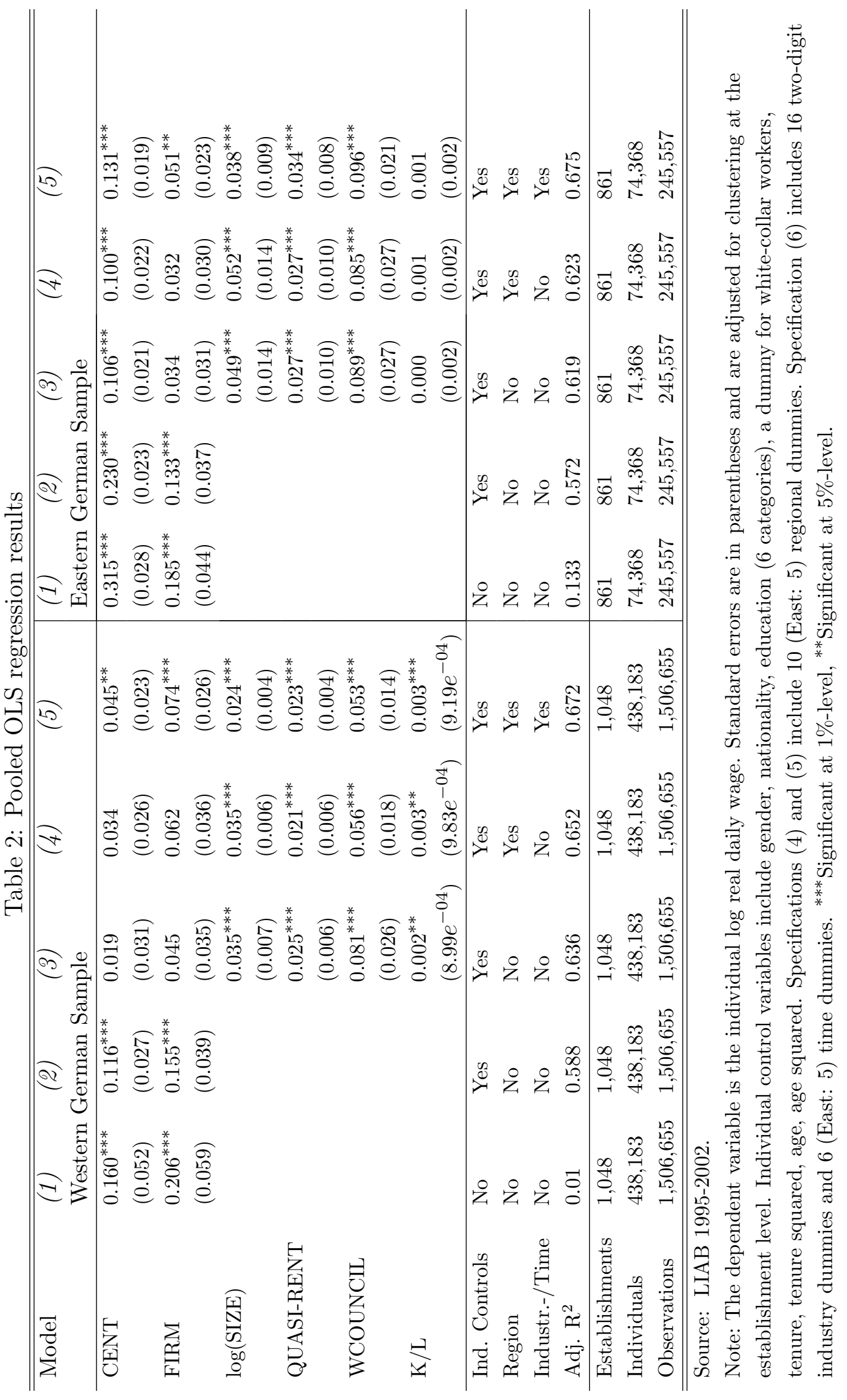


All establishment covariates enter the specification with their expected sign and are all significant at conventional levels (Model (3)). Establishment size, per-capita quasi-rents and the capital-labour ratio are found to have a significant positive effect on wages, a result which is consistent with what has been found earlier in the literature. ${ }^{10}$ To control for cross-state differences in wages, Model (4) includes regional dummies for 10 western German federal states. Controlling for establishment location leads to a larger and somewhat more precise estimate of the collective bargaining coefficients, indicating that bargaining coverage is particularly concentrated among states characterised by less favourable economic conditions. In Model (5), the inclusion of industry and time dummies leads to a further increase in the collective bargaining coefficients. This reflects the underlying industry distribution of collective contracts, which are relatively more frequent among low-wage sectors, such as the consumer-goods industries. From Model (1) to (5), the coefficient on industry contracts drops by about 70 per cent, while the coefficient on firm contracts decreases by about 65 per cent.

The right panel of Table 2 reports the POLS regression results using the eastern German sample. Including individual characteristics in Model (2) reduces the coefficient on centralised contracts from 0.315 to 0.230 and on firm-level contracts from 0.185 to 0.133 , indicating that individual observables account for a similar proportion of omitted variable bias as in the western German sample. From Model (1) to (5), the coefficient on industry contracts drops by about 60 per cent, while the coefficient on firm contracts decreases by 70 per cent. Overall, the results from Table 2 imply that observable establishment characteristics generally account for the largest proportion of omitted variable bias in the raw wage differentials. Systematic sorting of observably better firms into the regimes appears to be more relevant for industry-level contracts in western Germany and for firm-level contracts in eastern Germany.

As mentioned earlier, much of the empirical research on union wage effects suggests that unions do not only affect the mean but also the overall dispersion of wages through their impact on the returns to worker and firm attributes. To assess the impact of collective bargaining coverage on the overall wage structure, Table 3 reports the estimates of a fully interacted model, which includes interaction terms of all covariates with the contract status dummies.

\footnotetext{
${ }^{10}$ For firm size effects see e.g. Oi and Idson (1999), German evidence on employer size effects is provided by Schmidt and Zimmermann (1991). Hildreth and Oswald (1997) and Arai (2003) present international evidence on the wage-profit relationship, while evidence for Germany is documented in König and Hübler (1998) and Guertzgen (2005).
} 


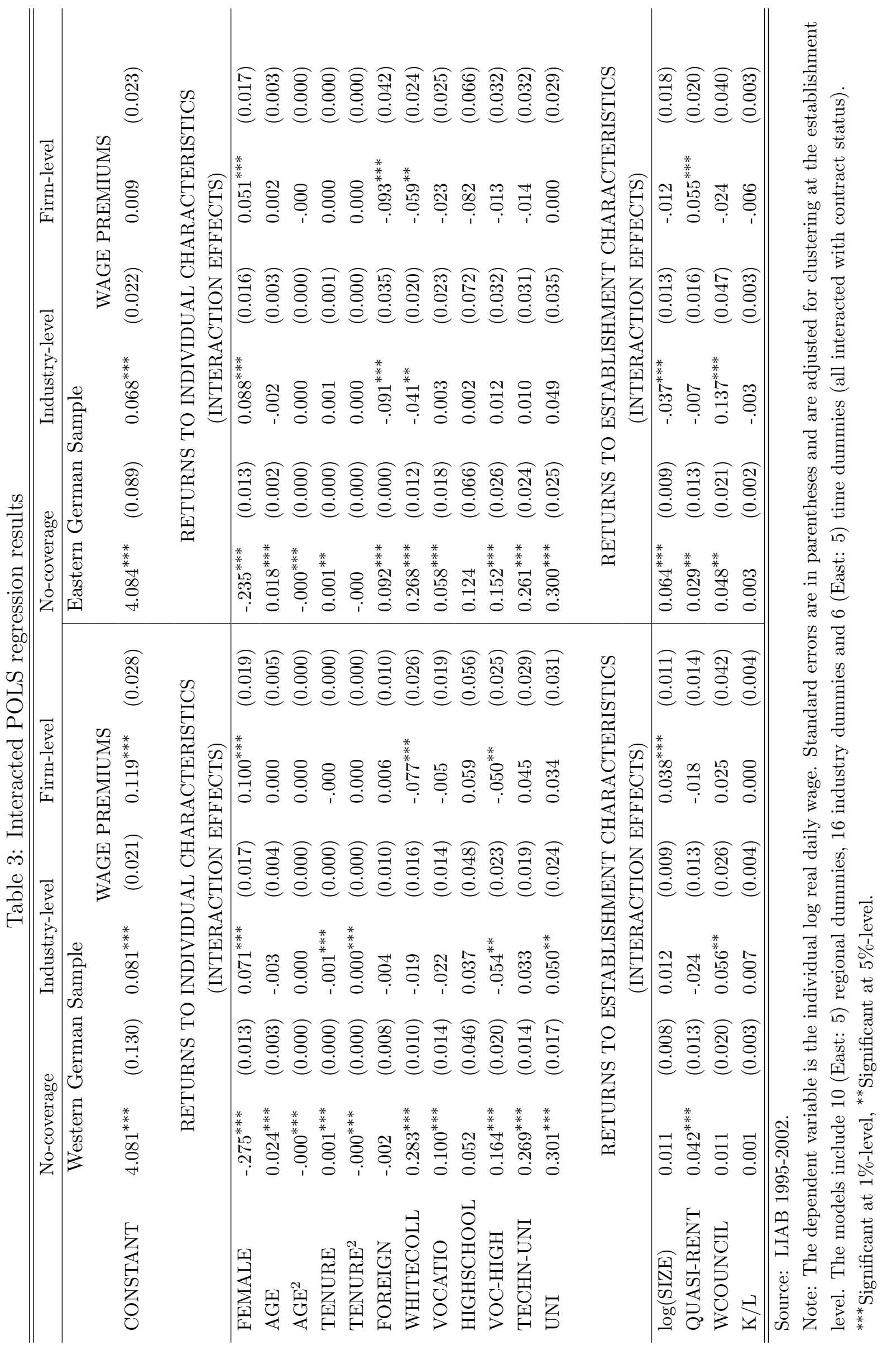


Recall that the interacted regressors are expressed in terms of deviations from their sample means, so that the estimated coefficient on firm-level and centralised contracts is to be interpreted as the wage premium for a worker with the average characteristics of the sample. The average wage premiums for centralised and firmlevel contracts are presented in the first row of columns (2) and (3), the interaction effects of individual and establishment level observables are shown below. Groupwise $F$-tests testing the joint significance of the interaction coefficients for industry and firm-level contracts reject the null-hypothesis of the equality of all the coefficients across the three regimes (with $P$-values close to zero). The results indicate that the estimated returns to most of the individual attributes such as gender, employment status, potential tenure and a vocational-plus-highschool qualification are smaller for covered individuals, which appears to support the view that collective bargaining contracts reduce skill and gender wage differentials. This pattern of results is similar to what has been found in the international literature and confirms recent findings by Stephan and Gerlach (2005) for Germany. Note, however, that the estimates do not reveal any clear pattern of the extent of wage compression under both contract types. While industry-level contracts appear to decrease the returns to tenure and to a vocational-plus-highschool degree to a larger extent than firm-level contracts, the reverse is true for the gender wage penalty and the returns to employment status.

As to the returns to establishment attributes, the estimated coefficients on percapita quasi-rents reveal that collective contracts appear to decrease the returns to establishment profitability, which has already been documented in earlier work (Guertzgen 2005). Finally, the results indicate that workers in covered establishments benefit the most from the existence of a works council. A possible explanation for this finding may relate to the fact that in covered establishments union density among works councils members is generally very high (Hassel 1999). To the extent that works councils in uncovered establishments are characterised by a fragmentation of interests, this may help to increase the local bargaining power of works councils in covered establishments. In sum, the estimated average wage premium is 0.081 for industry-level contracts and 0.119 for firm-level contracts, with both premiums being significant at the 1\%-level. These estimates are in a similar range compared with those obtained by Stephan and Gerlach (2005), who report coefficients between 0.088 and 0.114 on industry contracts and between 0.072 and 0.104 on firm contracts for 1995 and $2001 .^{11}$

\footnotetext{
${ }^{11}$ Note, however, that the authors use a different data set (the Salary and Wage Structure Survey from the West German Federal State of Lower-Saxony) and employ a different set of
} 
The right panel of Table 3 presents the results from the fully interacted specification using the eastern German sample. Inspection of the interaction coefficients reveals that, similar to the western German estimates, the estimated returns to employment status and the gender wage penalty are smaller for covered individuals. Note, however, that unlike in the western German sample especially industry-level contracts do not appear to exert any influence on the returns to skills. A further difference that emerges is that the interaction effect for works councils is found to be significant only under industry-level contracts, with the effect being much more pronounced than in establishments in western Germany (0.137 versus 0.056). Also noteworthy is the result that collective contracts are found to compress the returns to establishment size which distinguishes them further from their western German counterparts. As a result, the estimated average wage premium is 0.068 for industrylevel contracts and significant at the 1\%-level, while the point estimate for firm-level contracts is found to be very small (0.009) and not significantly different from zero.

\subsubsection{Individual and Establishment Heterogeneity}

Our earlier considerations from Section 3 suggested that the estimated wage effects might be biased due to a non-random selection of workers with unobservable skills and firms with unobservable attributes into the different regimes. To assess the extent to which sorting affects our estimates, we next attempt to control for individual- and establishment-specific unobservables by estimating a spell differenced specification. Note that the extent to which spell fixed-effects estimates differ from individual fixed-effects estimates largely depends on the fraction of individuals who move between establishments within our sample. In the extreme case of no turnover between sample establishments, spell and individual fixed-effects yield the same results, and $\alpha_{i}$ and $\phi_{j}$ cannot be separately identified. A closer examination of the distribution of the number of spells reveals that the majority of individuals do not move between sample establishments, only 827 out of 438,183 workers in the western German sample and 130 out of 74,368 workers in the eastern German sample (corresponding to 0.19 per cent in the western German and 0.17 per cent in the eastern German sample) move from one sample establishment to another. ${ }^{12}$

covariates. Further evidence based upon the Salary and Wage Structure Survey is provided by Heinbach (2005) and Fitzenberger et al. (2006). However, their results are not directly comparable to ours since Heinbach distinguishes industry-level contracts with and without opt-out clauses, while Fitzenberger et al. consider the impact of firm-specific shares of covered employees on wage outcomes.

${ }^{12}$ Note that the number of West German individuals $(438,183)$ plus the number of East German individuals $(74,368)$ exceeds the total number of individuals in our analysis $(512,507)$, since 22 individuals move between East and West Germany. 
Moreover, out of 503 establishments with sample movers, the majority (398) employ less than 5 movers (out of which 249 have only one single mover). As a consequence, we do not separately identify $\alpha_{i}$ and $\phi_{j}$ as proposed by Abowd et al. (1999), since for a large number of firms such an identification would have to rely on a very few number of movers to estimate the establishment effect. ${ }^{13}$

From eq. (3) it becomes evident that with the spell differenced specification the wage premiums associated with firm and industry-level contracts are identified solely from within-establishment variation in contract status. To gain an idea of the underlying dynamics with respect to collective bargaining status, Table 4 reports the number of observed transitions between the three regimes. ${ }^{14}$

Table 4: Changes in contract status

\begin{tabular}{|c|c|c|c|c|}
\hline $\begin{array}{l}\text { Transitions } \\
\text { from }\end{array}$ & Industry-level & Firm-level & \multicolumn{2}{|c|}{ Western German Sample } \\
\hline Industry-level & 688 & 15 & 29 & $732(69.8 \%)$ \\
\hline Firm-level & 21 & 58 & 16 & $95(9.1 \%)$ \\
\hline No-coverage & 40 & 9 & 172 & $221(21.1 \%)$ \\
\hline & $749(71.5 \%)$ & $82(7.8 \%)$ & $217(20.7 \%)$ & 1,048 \\
\hline $\begin{array}{l}\text { Transitions } \\
\text { from }\end{array}$ & Industry-level & Firm-level & $\begin{array}{l}\text { Easter } \\
\text { No-coverage }\end{array}$ & rman Sample \\
\hline Industry-level & 224 & 13 & 46 & $283(32.9 \%)$ \\
\hline Firm-level & 15 & 44 & 42 & $101(11.7 \%)$ \\
\hline No-coverage & 31 & 24 & 422 & $477(55.4 \%)$ \\
\hline & $270(31.4 \%)$ & $81(9.4 \%)$ & $510(59.2 \%)$ & 861 \\
\hline
\end{tabular}

Source: LIAB 1995-2002. The figures refer to the number of establishments.

Closer inspection of the off-diagonal entries in the upper panel of Table 4 shows that in the western German sample 130 out of 1,048 establishments changed contract status in the time period under consideration, with the biggest movement taking place between no-coverage and industry-level contracts. The lower panel of Table 4 shows that establishments in eastern Germany exhibit stronger variation in contract status, with 171 out of 861 establishments changing contract status between 1996 and 2002 .

\footnotetext{
${ }^{13}$ The low proportion of movers is due to the fact that the linked Employer-Employee data set is based on a sample of establishments. As a result, the probability of observing workers moving from one sample establishment to another is very low. It is important to note that the low proportion of movers does not imply that our data set is restricted to very stable employment relationships as workers (and firms) may enter and exit the panel.

${ }^{14}$ The number of individuals affected by each transition are reported in Table 7 .
} 


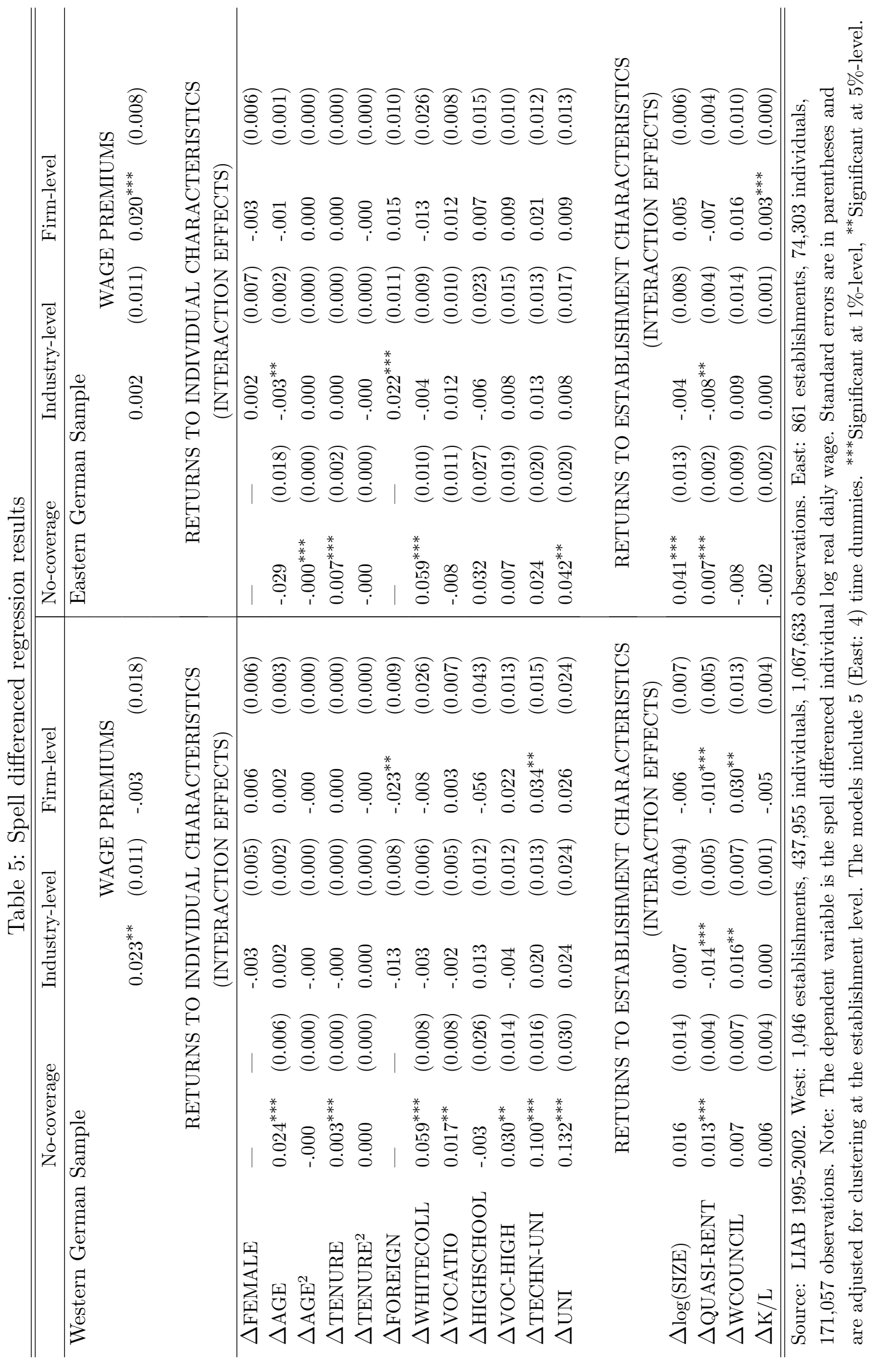


In addition, the figures indicate that in the western German sample the number of establishments becoming uncovered (45 "quitters") is roughly matched by the number of establishments becoming covered (49 "joiners"). On the contrary, in the eastern German sample the number of quitting establishments (88) is found to exceed that of joining establishments (55) by about 60 per cent.

The left panel of Table 5 reports the spell differenced estimates using the western German sample. Since differencing requires at least two consecutive time periods within each spell, we need to exclude 830 spells with only one observation per spell and the number of observations drops to $1,067,633 .{ }^{15}$ The average wage premiums for centralised and firm-level contracts are presented in the first row of columns (2) and (3), the interaction effects of individual and establishment level observables are shown below. The results from the spell differenced regressions imply a wage markup of about 0.02 under industry-level contracts, which is statistically significant at the 5\%-level. These results imply that for a worker with the average characteristics of the sample the wage premium under centralised contrast decreases by about 75 per cent once the non-random selection of workers and firms into the bargaining regimes is accounted for. By contrast, the wage premium under firm-level contracts is estimated to be negative and not significantly different from zero, indicating that a positive selection is even more relevant under firm-level contracts. Closer inspection of the interaction effects in Table 5 reveals that compared with the POLS specification the estimated returns to most of the individual attributes are not significantly smaller for covered individuals (with the exception of the wage penalty for foreign workers which is significantly larger under firm-level contracts). Note that this pattern of results is consistent with the notion that the flattening of the wage structure that emerged from the simple POLS specification arises from a selectivity bias, since workers with low levels of observed skills tend to be positively selected and workers with higher levels of observed skills tend to be negatively selected into covered firms.

To highlight this selection process, it may be instructive to compare the industrylevel wage premium among workers without any degree to the premium among workers with a vocational-plus-highschool degree. For the latter, the wage premium resulting from the interacted POLS specification is 0.038 and decreases to 0.015 in the spell differenced specification. By comparison, for a worker without any degree the interacted POLS specification implies a wage premium of 0.092, which drops to

\footnotetext{
${ }^{15}$ Out of 439,013 spells, 830 spells have only one observation. The remaining number of spells is 438,183 . The exclusion of the 830 one-observation-spells leads to 9 spells exhibiting a gap in their time series. Since one observation per spell is lost in first-differencing within each spell, the number of observations drops to $1,067,633$.
} 
0.019 once the selection into the regimes is accounted for. As a result, the estimates of the equalising effect of industry-level contracts on low-skilled workers from the POLS specification considerably overstate the true equalising effect.

Turning to the interaction terms of the establishment effects, the estimates partly confirm the pattern of the interacted POLS specification, with industry and firmlevel contracts decreasing the returns to establishment profitability and raising the returns to a works council. Under firm-level contracts the positive interaction coefficient on firm size from Table 3 disappears once the selectivity into the regimes is taken into consideration. This finding provides some support of a positive selection upon unobservables among large establishments into this contract type or, alternatively, of a systematic selection of individuals with high unobservable skills into very large covered establishments. A similar result holds with respect to quasi-rents as the interaction coefficient on quasi-rents decrease relatively less than the average wage premium, indicating a positive worker and firm selection into collective bargaining coverage among highly profitable establishments.

The right panel of Table 5 presents the spell differenced estimates using the eastern German sample. ${ }^{16}$ Interestingly, compared with the western German sample the results are reversed, with firm-level contracts leading to a slightly larger wage mark-up than in the POLS specification, which is statistically significant at the 1\%-level. By contrast, the wage premium under industry-level contracts is found to be insignificant. Thus, similar to the western German results, the differenced specifications tend to reverse the ranking of the wage premiums obtained from the POLS specifications. Comparing the interaction coefficients for white-collar workers from Table 3 and 5 indicates that the flattening of the wage structure among blue and white-collar workers that emerged from the interacted POLS specification again arises from a selectivity bias, with white-collar workers being negatively selected into covered firms. Further, inspection of the interaction terms on quasi-rents in Table 3 and 5 reveals that the firm-level contract wage premium resulting from the POLS specification appears to be upward biased especially in highly profitable establishments. This finding is indicative of a systematic selection of individuals with high unobservable productivity into above average profitable establishments that are covered by a firm-level contract or, alternatively, of a positive selection upon unobservables among highly profitable establishments into firm-level contracts.

\footnotetext{
${ }^{16}$ In the East German sample, out of 74,498 spells 165 spells exhibit only one observation per spell. The remaining number of spells is 74,333. The exclusion of the 165 one-observation-spells leads to 2 spells exhibiting a gap in their time series. Since one observation per spell is lost in first-differencing within each spell, the number of observations drops to 171,057.
} 


\subsubsection{Wage Decomposition}

In this section, we use the estimates from Table 5 to decompose the wage differentials between the three regimes into a true coverage effect and a selection effect. Consider, for example, the wage differential between industry-level contracts and no-coverage. From the interacted specification, the unadjusted wage gap may be written as:

$$
\begin{aligned}
\overline{\ln w_{C}}-\overline{\ln w_{N}}= & {\left[\gamma_{C}+\beta_{C} \cdot\left(\bar{x}_{C}-\bar{x}\right)+\delta_{C} \cdot\left(\bar{u}_{C}-\bar{u}\right)+\eta_{C} \cdot\left(\bar{w}_{C}-\bar{w}\right)+\rho_{C} \cdot\left(\bar{q}_{C}-\bar{q}\right)\right] } \\
& +\left[\beta \cdot\left(\bar{x}_{C}-\bar{x}_{N}\right)+\eta \cdot\left(\bar{w}_{C}-\bar{w}_{N}\right)\right] \\
& +\left[\left(\overline{\varphi_{C}+\vartheta_{C}}\right)-\left(\overline{\varphi_{N}+\vartheta_{N}}\right)\right]
\end{aligned}
$$

where variables with bars (and subscripts $N$ and $C$ ) represent sample means of the respective variables (under no-coverage $(N)$ and industry-level contracts $(C)$ ). ${ }^{17}$ The first term in brackets represents the effect of industry-level contracts on wages of individuals who are employed by covered establishments, whereas the second term in brackets represents the part of the wage gap that may be attributed to observed differences in time-variant individual and establishment characteristics. Finally, the last term in brackets reflects differences due to the selection upon time-constant observable as well as time-constant unobservable individual and establishment level attributes. Analogous expressions may be derived for wage differentials between firm-level contracts and no-coverage and those between industry and firm-level contracts. Table 6 presents the decomposition of wage differentials between the different regimes. For the western German sample, the figures in column (1) in the upper panel disclose that the unadjusted wage gap under industry-level contracts relative to uncovered firms consists of a coverage effect of 0.024 and a selection bias of 0.135 . The largest part of the selection effect can be attributed to differences in (timevarying) establishment and individual observables. The decomposition in column (2) suggests a much larger relative selection effect under firm-level contracts, with the selection bias even exceeding the unadjusted wage gap. Similarly, decomposing the raw wage difference between industry-level and firm-level contracts shows that the negative wage gap mainly arises from a selection upon unobservables (and time-constant attributes), which is found to exceed the overall coverage effect of

${ }^{17}$ For each spell $s$, an estimator of $\theta_{s}=\left(\varphi_{s}+\vartheta_{s}\right)$ is calculated as follows:

$$
\begin{gathered}
\widehat{\theta}_{s}=\overline{\ln }_{s}-\gamma_{C} \cdot \bar{C}_{s}-\gamma_{F} \cdot \bar{F}_{s}-\beta \cdot \bar{x}_{s}-\eta \cdot \bar{w}_{s} \\
\beta_{C} \cdot \bar{C}_{s} \cdot\left(\bar{x}_{s}-\bar{x}\right)+\eta_{C} \cdot \bar{C}_{s} \cdot\left(\bar{w}_{s}-\bar{w}\right) \\
\beta_{F} \cdot \bar{F}_{s} \cdot\left(\bar{x}_{s}-\bar{x}\right)+\eta_{F} \cdot \bar{F}_{s} \cdot\left(\bar{w}_{s}-\bar{w}\right),
\end{gathered}
$$

where variables with bars denote averages over all time-series observations within each spell. 
industry-level contracts. In other words, if workers and firms under industry contracts were to exhibit the same unobservable characteristics as those under firm-level contracts, we would observe an average unadjusted wage gap of about 0.04 . Turning to the total coverage effect, the figures disclose that the effect of industry-level contracts relative to firm-level contracts and no-coverage mainly consists of an average effect, whereas the overall effect on the returns to observable attributes appears to be negligible. Firm-level contracts, in contrast, seem to compress the returns to observables relative to industry-level contracts and no-coverage, though to a rather small extent.

Table 6: Wage Decomposition

\begin{tabular}{|c|c|c|c|}
\hline Western German Sample & $\begin{array}{l}\text { Industry-level } \\
\text { vs. no-coverage }\end{array}$ & $\begin{array}{l}\text { Firm-level } \\
\text { vs. no-coverage }\end{array}$ & $\begin{array}{l}\text { Industry- } \\
\text { vs. firm-level }\end{array}$ \\
\hline Average effect & 0.023 & -.003 & 0.026 \\
\hline \multicolumn{4}{|l|}{ Effect on the returns } \\
\hline to observed attributes & 0.001 & -.013 & 0.015 \\
\hline TOTAL COVERAGE EFFECT & 0.024 & -.016 & 0.041 \\
\hline Differences in time-var. attributes & 0.099 & 0.107 & -.009 \\
\hline \multicolumn{4}{|l|}{ Differences in unobserved and } \\
\hline time-constant attributes & 0.037 & 0.114 & -.077 \\
\hline TOTAL SELECTION BIAS & 0.135 & 0.221 & -.086 \\
\hline Unadjusted wage gap & 0.160 & 0.205 & -.045 \\
\hline \multirow[b]{2}{*}{ Eastern German Sample } & Industry-level & Firm-level & Industry- \\
\hline & vs. no-coverage & vs. no-coverage & vs. firm-level \\
\hline Average effect & 0.001 & 0.020 & -.019 \\
\hline \multicolumn{4}{|l|}{ Effect on the returns } \\
\hline to observed attributes & 0.001 & 0.001 & 0.001 \\
\hline TOTAL COVERAGE EFFECT & 0.002 & 0.021 & -.018 \\
\hline Differences in time-var. attributes & 0.127 & 0.025 & 0.101 \\
\hline \multicolumn{4}{|l|}{ Differences in unobserved and } \\
\hline time-constant attributes & 0.186 & 0.139 & 0.047 \\
\hline TOTAL SELECTION BIAS & 0.313 & 0.164 & 0.148 \\
\hline Unadjusted wage gap & 0.315 & 0.185 & 0.130 \\
\hline
\end{tabular}

Source: LIAB 1995-2002. The calculations are based upon the estimates from Table 5.

The lower panel of Table 6 presents the decomposition of wages using the eastern German sample. Similar to the western German results, differences in observables and unobservables account for the largest proportion of the raw wage gaps under firm and industry-level contracts relative to uncovered firms. compared with western Germany, the selection upon unobservables and time-invariant observables appears 
to be relatively more important under both contract types. Finally, the results in column (3) suggest that differences in observables explain the largest part of the unadjusted wage differential between industry-level versus firm-level contracts. In sum, the total selection bias is found to exceed the observed positive raw wage differential. I.e., if workers and firms under industry contracts exhibited the same observable and unobservable characteristics as those under firm-level contracts, this would result in a negative unadjusted wage gap. Turning to the total coverage effect, the overall effect on the returns to observable attributes is found to be negligible under both contract types.

\subsubsection{Analysing Separate Transitions}

As noted earlier, in eq. (3) $\gamma_{C}$ and $\gamma_{F}$ are identified from variations in contract status, i.e. if $\Delta C_{j t} \neq 0$ and $\Delta F_{j t} \neq 0$. Thus far, it has been assumed that the effects of the transitions are symmetric. However, it might be possible that of those establishments who change contract status, those who become covered by a collective contract experience a different wage effect than those who leave that collective contract type. To gain an idea about the extent of such potential asymmetries, we now separately analyse transitions from one regime to the other by estimating the spell differenced specification for each possible transition. We then contrast the wage growth of individuals experiencing a change in contract status to the wage growth of two different comparison groups. The first one comprises those individuals that stay in the origin regime, while the second one consists of those always being covered by the destination regime. To assess potential differences in outcomes, Table A3 and A4 in the appendix further present characteristics of changing establishments compared with those in the reference groups. As set out in Section 4.1., comparing those characteristics turns out to be instructive, since changes in time-specific shocks may differ systematically across establishments that change contract status and those that retain their contract status. As the coefficients on $\Delta C_{j t}$ and $\Delta F_{j t}$ will be biased, if $\Delta C_{j t}$ and $\Delta F_{j t}$ are correlated with $\Delta \varepsilon_{i j t}$, this may help to explain potential differences in estimated wage effects. Closer inspection of differences in observable characteristics then may give us some further indication about the severity of a potential endogeneity bias as it seems reasonable to assume that differences in unobservable factors are likely to be correlated with differences in observables.

The estimated coefficients on industry-level and firm-level contracts along with their standard errors are presented in Table 7, which reads as follows. The first row, for example, presents the spell differenced estimates of $\gamma_{C}$ using the transitions from firm-level to industry-level contracts. In the third column, the wage premi- 
ums are estimated by contrasting the wage gain of individuals experiencing such a change in contract status to the wage gain of those individuals always being covered by firm-level contracts. The number in parentheses $(N)$ refers to the number of individuals subject to the change in contract status. In the second column, in contrast, the wage gain is compared to the wage gain of individuals always being covered by industry-level contracts. Consider first the upper panel of Table 7, which presents the estimates using the western German sample. The figures in the second row indicate that the relative wage loss of individuals that experience a change from industry- to firm-level contracts appears to be quite uniform irrespective of the chosen comparison group (about -0.03). By contrast, analysing the wage premium for firm-level to industry-level contract transitions yields a somewhat different picture. Here, the point estimate obtained from the comparison with establishments always being covered by a firm-level contract is found to be much smaller $(0.006$ versus 0.047). Inspection of Panels $\mathrm{B}$ and $\mathrm{C}$ in Table A3 in the appendix reveals that this may arise from systematic differences in observables, with establishments joining industry-level contracts being considerably smaller, less capital-intensive and profitable than those always being covered by firm-level contracts. Thus, the "joiners" of industry level contracts arguably might have experienced (more) negative time-specific shocks, leading to a downward biased estimate of $\gamma_{C}$.

Analysing separate transitions between no-coverage and industry-level contracts yields a rather inconsistent pattern. The figures in row (3) and (4) show that both transitions - leaving and joining industry-level contracts - entail positive wage effects. The result that individuals in leaving establishments experience a relative wage gain appears to be contra-intuitive and therefore deserves somewhat closer attention. As noted above, a possible explanation might be that establishments in the corresponding comparison groups do systematically differ from those leaving industry-level bargaining. Inspection of Panels A and B in Table A3 in the appendix reveals that this appears indeed to be the case for either reference group. The most striking difference between the reference groups and "quitting" plants is that the latter are considerably more capital intensive. Based on this observable difference one might conjecture that the decision to leave industry-level contracts is driven by factors other than wage outcomes, such as more flexibility with respect to working time and the use of overtime hours.

Finally, consider the transitions between no-coverage and firm-level contracts. The figures in column (3) of row (5) and (6) indicate that both transitions give rise to negative wage effects when choosing individuals in establishments always 
being covered by firm-level contracts as the reference group. However, Panels A and $\mathrm{C}$ of Table A3 in the appendix reveal that the latter appear to be an inappropriate comparison group given that those establishments are considerably larger, more profitable and capital intensive than those leaving or joining firm-level contracts, suggesting that these estimates might be downward biased. Based on this evidence, the (insignificant) estimates obtained from the comparison with establishment always being uncovered appear to be more reliable, since the latter do not exhibit such striking differences in observables. However, a further concern might be that the insignificant wage premium in row (6) is driven by a change in the survey question between 1997 and 1998, which might have induced spurious changes from firm-level contracts to no-coverage in $1998 .{ }^{18}$ To check whether our results are affected by this change, we re-ran the regressions after excluding all establishments leaving firm-level contracts in 1998 from our sample (4 establishments in western Germany and 8 establishments in eastern Germany). While the results for eastern Germany appeared to be quite robust to this exclusion, the estimated wage effect for the western German sample reported in column (1) and row (6) changed to -0.058 (with a standard error of 0.035 ) and to -0.062 in column (3) (with a standard error of 0.037 ). In light of the sensitivity of the results to this exclusion and the small number of regime switchers between firm-level contracts and no-coverage in the western German sample, these results are therefore to be interpreted with particular caution.

The lower panel of Table 7 presents the estimates using the eastern German sample. While the firm-level/industry-level contract transitions yield a quite consistent picture, the transitions between no-coverage and industry-level contracts show a rather unsatisfactory pattern. The figures in row (3) and (4) indicate that workers in establishments leaving industry-level bargaining incur a relative wage loss (corresponding to a positive wage mark-up of industry-level contracts), while those joining industry-level contracts experience a (significant) negative effect, at least compared with those employed by establishments that are always covered by an industry-level contract. However, inspection of Panel A and B in Table A4 shows that the latter are considerably larger, more profitable and capital-intensive than those joining industry-level bargaining, indicating that the wage effect may be downward biased

\footnotetext{
${ }^{18}$ In 1998, the survey question concerning firm-level contracts changed from "In this establishment, is there a firm-level contract in force?" to "... is there a firm-level contract in force that has been concluded between this establishment and a trade union?" (author's translation). Arguably, this may have induced spurious changes from firm-level contracts to no-coverage in 1998 for all those establishments incorrectly reporting the existence of a firm-level contract prior to 1998 (e.g. those having concluded a plant-level agreement with their works council).
} 
Table 7: Analysis of Separate Transitions

Average wage gain (loss) compared with workers in plants that always adopt:

\begin{tabular}{llll} 
Western German Sample: & No-coverage & Industry-level & Firm-level \\
\hline Transition: & & & \\
(1) Firm-level to industry-level $(N=2,741)$ & & $0.047^{* * *}(0.014)$ & $0.006(0.016)$ \\
(2) Industry-level to firm-level $(N=3,854)$ & & $-.033(0.018)$ & $-.035(0.023)$ \\
& & \\
(3) No-coverage to industry-level $(N=2,028)$ & $0.017(0.010)$ & $0.034^{* * *}(0.009)$ & \\
(4) Industry-level to no-coverage $(N=1,827)$ & $0.046^{* *}(0.018)$ & $0.022(0.012)$ & \\
& & & $-.064^{* * *}(0.012)$ \\
(5) No-coverage to firm-level $(N=545)$ & $-.021(0.030)$ & & $-.032^{* * *}(0.015)$ \\
(6) Firm-level to no-coverage $(N=1,303)$ & $-.001(0.017)$ & &
\end{tabular}

Average wage gain (loss) compared with workers in plants that always adopt:

Eastern German Sample: $\quad$ No-coverage $\quad$ Industry-level Firm-level

Transition:

(1) Firm-level to industry-level $(N=2,197)$

$$
-.064^{* * *}(0.019) \quad 0.002(0.021)
$$

(2) Industry-level to firm-level $(N=2,175)$

$0.034^{* * *}(0.006) \quad 0.023^{* * *}(0.008)$

(3) No-coverage to industry-level $(N=662) \quad-.010(0.033) \quad-.088^{* * *}(0.033)$

(4) Industry-level to no-coverage $(N=1,716) \quad-.026^{* *} \quad(0.012) \quad-.083^{* * *} \quad(0.017)$

(5) No-coverage to firm-level $(N=960) \quad 0.024^{* *}(0.010) \quad 0.013(0.015)$

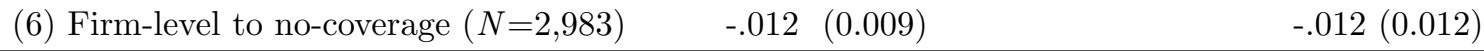

Source: LIAB 1995-2002. The estimates of the wage premiums are obtained by estimating the interacted spell differenced specification using the respective subsamples of establishments (those that experience the change in contract status and those that retain their contract status). $N$ refers to the number of individuals experiencing the transitions. 
due to a negative correlation of unobservables with contract change. The same argument holds when analysing leaving establishments (see Panel A and B in Table A4). The estimates in row (4) show that there is indeed some evidence of a downward biased estimate when comparing leaving establishments with those always adopting industry contracts, since the implied negative wage effect is much larger relative to a comparison with uncovered establishments (-0.083 versus -0.026$)$. In sum, the analysis of the separate transitions leads us to conclude that the overall insignificant coefficient on industry contracts in Table 5 arises from a negative wage effect for those leaving industry-level bargaining (implying a positive wage premium of industry contracts) and a negative wage premium for those joining industry-level contracts, with both effects approximately offsetting each other in the pooled specification. Analysing separate transitions between no-coverage and firm-level contracts yields a more consistent picture, with firm-level contract "joiners" experiencing a relative wage gain and "leavers" suffering a relative wage loss. However, comparing the observables of "joiners" and uncovered establishments in Panel A of Table A4 reveals that the former are considerably more capital-intensive and profitable than those who always stay uncovered. Based on this evidence the estimated wage premium of about 0.024 might still be upward biased, if "joiners" of firm-level contracts have experienced a (more) positive change in time-specific shocks.

Taken together, the estimates from Table 7 suggest a quite stable pattern with respect to the transitions between industry-level and firm-level contracts. However, the results also indicate that the estimated wage premiums relative to uncovered firms need to be interpreted with some caution. This is not only because of the small number of establishments experiencing such a change in contract status but also because of the striking dissimilarities between regime switchers and those that retain their contract status. For industry-level contracts, the figures indicate that in western Germany the effect might be biased downward by the wage gain of those establishments that leave industry-level bargaining, while in eastern Germany the effect might be confounded by the relative wage loss experienced by those joining industry-level contracts. A further caveat to our conclusions is that our identification strategy cannot rule out the possibility that the small estimated wage premiums may be an artefact of formal contract changes that are not paralleled by changes in actual wage policies. For example, the small wage effects might be driven by the fact that those establishments who change from no-coverage to industry-level contracts already informally followed the terms of such contracts (or, alternatively, that those who formally leave industry-level bargaining keep applying the contract 
terms). ${ }^{19}$ For this reason, we emphasise that our estimated wage premiums need to be interpreted as wage mark-ups associated with a legally binding collective wage agreement.

\section{Summary and Conclusions}

Using a large linked employer-employee data set, this paper has provided new evidence on collective bargaining wage premiums in Germany. By using longitudinal data, we seek to improve on recent evidence relying on cross-sectional data to identify the collective bargaining effect. Summing up, our results indicate that in western Germany about 70 per cent of the wage premium associated with industry contracts and 65 per cent of the wage premiums associated with firm-level contracts can be explained by differences in observables. In eastern Germany, the wage premiums associated with industry and firm-level contracts drop by 60 and 70 per cent, once differences in observables are controlled for. Overall, the results suggest that differences in firm characteristics account for the largest proportion of omitted variable bias. Systematic sorting of observably better firms into the regimes appears to be more relevant for industry contracts in western Germany and for firm-level contracts in eastern Germany. The estimates from a fully interacted specification appear to support the hypothesis that unions compress some of the returns to observable worker attributes. However, the results from our differenced specifications show that a large part of this flattening of the wage structure arises from a selectivity bias, as workers with low levels of observable skills are positively and workers with higher levels of skills are negatively selected into covered firms. In sum, our wage decompositions indicate that the overall effect of collective bargaining coverage on the returns to observable attributes appears to be rather negligible once the selection into the regimes is accounted for.

Overall, the differenced specifications suggest the following conclusions. First, differences in observables and unobservables appear to explain the full firm-level contract wage premium in western Germany and the full premium associated with industry-level contracts in eastern Germany. Second, there remains a small, but

\footnotetext{
${ }^{19}$ Unfortunately, information on whether establishments without any binding collective contract use the terms of an industry-wide agreement as a point of reference is available only from 1999 onwards in our data set. For those establishments who leave industry-level contracts this would reduce the available waves to the period 1999 to 2001 and for those entering industry-level bargaining to the period 2000 to 2001. Clearly, this restriction would lead to a substantial decrease in the number of establishments changing contract status from which estimates of the wage premiums could be identified.
} 
statistically significant wage premium of about 2 per cent for industry-level contracts in western Germany and a similar premium for firm-level contracts in eastern Germany. Overall, the results from the differenced specifications tend to reverse the ranking of the wage premiums obtained from the POLS specifications. In failing to detect substantial wage premiums relative to uncovered firms, our findings seem to be in line with the results reported by Hartog et al. (2002), who find no evidence of substantial industry and firm-level contract wage premiums for the Netherlands. The authors interpret this result as a consequence of the relatively corporatist Dutch wage determination system. Note that a similar conclusion might apply to Germany, where centralised unions are likely to internalise negative externalities resulting from their wage demands. However, our analysis of separate transitions based upon comparisons with different reference groups suggests that the small identified wage effects should be interpreted with some caution. In particular, the results indicate that in western Germany the industry-level wage premium relative to uncovered firms might be biased downward by the relative wage gain of those establishments that leave industry-level bargaining, while in eastern Germany the effect might be confounded by the relative wage loss experienced by those joining industry-level contracts. Bearing these objections in mind, our analysis nevertheless yields estimates that depart from those obtained using cross-sectional data, suggesting that previous estimates might be considerably upward biased.

The result that selection into industry-level contracts appears to be somewhat more relevant in eastern Germany might be explained by the fact that the decision of joining or leaving an employers' association here is to a considerably larger extent left to the firm's discretion than in western Germany. In other words, only those eastern German firms that would have paid higher wages anyway are likely to adopt such industry-level contracts. In eastern Germany, firm-level contracts then are the only means left to unions of exerting their bargaining power and driving a wedge between wages of comparable workers in firms adopting such a contract and those that do not. In western Germany, in contrast, membership in an employers' association is likely to be more exogenous, since it presumably reflects to a larger extent the result of a historically grown industrial relations structure.

Finally, we wish to note that there are several potential directions for future research. First, we have focused on the impact of a change in contract status on wages. Future research should address the question as to how other outcomes such as employment and investment decisions are affected by collective bargaining coverage. Second, our analysis was confined to the short-run effects of a change in contract 
status. Further investigations should go into the long-run effects in order to explore whether there are possible dynamics in the response of wages to a change in contract status. Ideally, this requires the availability of a considerably longer panel data set, which would allow one to track a sufficiently large number of establishments changing contract status over a longer time period. 


\section{References}

[1] Abowd, J. M., Kramarz, F. and D. N. Margolis (1999), High-wage workers and high-wage firms, Econometrica 67, 251-333.

[2] Addison, J., Schnabel, C. and J. Wagner (2006), The (parlous) state of German unions, IZA-Discussion Paper No. 2000, forthcoming in: Journal of Labor Research.

[3] Agell, J. and K. Lommerud (1992), Union egalitarianism as income insurance, Economica 59, 295-310.

[4] Andrews, M. J., Stewart, M. B., Swaffield, J. K. and R. Upward (1998), The estimation of union wage differentials and the impact of methodological choices, Labour Economics 5, 449-474.

[5] Andrews, M., Schank, T. and R. Upward (2005), Practical estimation methods for linked employer-employee data, IAB Discussion Paper 29/2005, Nürnberg.

[6] Arai, M. (2003), Wages, profits and capital-intensity: evidence from matched worker-firm data, Journal of Labor Economics 21, 593-618.

[7] Bellmann, L., Kohaut, S. and M. Lahner (2002), Das IAB-Betriebspanel Ansatz und Analysepotenziale, in: Kleinhenz, G. (ed.), IAB-Kompendium Arbeitsmarkt- und Berufsforschung, Beiträge zur Arbeitsmarkt- und Berufsforschung 250, 13-20, Nürnberg.

[8] Bender, S. , A. Haas and C. Klose (2000), IAB-Employment Subsample 19751995. Opportunities for analysis provided by the anonymised subsample, IZA Discussion Paper No. 117, Bonn.

[9] Blanchflower, D. (1991), Fear, unemployment and pay flexibility, Economic Journal 101, 483-496.

[10] Burda, M. (1995), Unions and wage insurance, CEPR Discussion Paper No. 1232 .

[11] Calmfors, L. and J. Driffill (1988), Centralization of wage bargaining, Economic Policy 6, 12-61.

[12] Calmfors, L. (2001), Wages and wage-bargaining institutions in the EMU - a survey of the issues, Empirica 28, 325-351. 
[13] Card, D. (1996), The effect of unions on the structure of wages: A longitudinal analysis, Econometrica 64, 957-979.

[14] Card, D. and S. de la Rica (2006), Firm-level contracts and the structure of wages in Spain, Industrial and Labor Relations Review 59, 573-592.

[15] Cardoso, A. R. and P. Portugal (2005), Contractual wages and the wage cushion under different bargaining settings, Journal of Labor Economics 23, 875-902.

[16] Davidson, C. (1988), Multiunit bargaining in oligopolistic industries, Journal of Labor Economics 6, 397-422.

[17] DiNardo, J. and D. S. Lee (2004), Economic impacts of new unionization on private sector employers: 1984-2001, Quarterly Journal of Economics 119, 13831440.

[18] Farber, H. (1983), The determination of the union status of workers, Econometrica 51, 1417-1437.

[19] Fitzenberger, B., Osikominu, A. and R. Völter (2005), Imputation rules to improve the education variable in the IAB Employment Subsample, ZEWDiscussion Paper 05-10, Mannheim.

[20] Fitzenberger, B., Kohn, K. and A. Lembcke (2006), Union wage effects in Germany: Union density or collective bargaining coverage?, Unpublished manuscript. Frankfurt.

[21] Gartner, H. (2005): The imputation of wages above the contribution limit with the German IAB employment sample. FDZ Methodenreport Nr. 02/2005, Nürnberg.

[22] Gesamtmetall (2006), Daten in Zeitreihen, http://www.gesamtmetall.de.

[23] Guertzgen, N. (2005), Rent-sharing and collective bargaining coverage - evidence from linked employer-employee data, ZEW-Discussion Paper 05-90, Mannheim.

[24] Hartog, J., Leuven, E. and C. Teulings (2002), Wages and the bargaining regime in a corporatist setting: the Netherlands, European Journal of Political Economy 18, 317-331.

[25] Hassel, A. (1999), The erosion of the German system of Industrial Relations, British Journal of Industrial Relations 37, 483-506. 
[26] Heinbach, W.D. (2005), Impact of opening clauses on bargained wages, IAWDiscussion-Paper No. 22. Tübingen.

[27] Hildreth, Andrew K. G. and Andrew J. Oswald (1997), Rent-sharing and wages: evidence from company and establishment panels, Journal of Labor Economics $15,318-337$.

[28] Hübler, O. and A. König (1998), Produktmarkteinflüsse, Renten und Löhne: Eine semiparametrische Untersuchung, in: Gerlach, Knut (ed.): Ökonomische Analysen betrieblicher Strukturen und Entwicklungen: das Hannoveraner Firmenpanel, 119-143. Frankfurt.

[29] Hübler, O. and U. Jirjahn (2003), Works councils and collective bargaining in Germany: The impact on productivity and wages, Scottish Journal of Political Economy 51, 471-492.

[30] Hunt, J. (2001), Post-unification wage growth in eastern Germany, Review of Economics and Statistics 87, 190-195.

[31] Lemieux, T. (2000), Estimating the effect of unions on wage inequality in an panel data model with comparative advantage and nonrandom selection, Journal of Labor Economics 16, 261-291.

[32] Moene, K. O., Wallerstein, M. and M. Hoel (1993), Bargaining structure and economic performance, in: Trade union behaviour, pay-bargaining and economic performance, eds. Flanagan, R. J., Moene, K. O. and M. Wallerstein, Oxford: Clarendon Press.

[33] OECD (1997), Employment Outlook 1997. Paris.

[34] OECD (2004), Employment Outlook 2004. Paris.

[35] Oi, W. Y. and T. L. Idson (1999), Firm size and wages, in: Ashenfelter, O. and D. Card, Handbook of Labor Economics. Vol. 3, Amsterdam.

[36] Oswald, A. J. (1982), The microeconomic theory of the trade union, The Economic Journal 92, 576-595.

[37] Schmidt, C. M. and K. F. Zimmermann (1991), Work characteristics, firm size and wages, Review of Economics and Statistics 73, 705-710.

[38] Schnabel, C., Zagelmeyer, S. and S. Kohaut (2006), Collective bargaining structure and its determinants: an empirical analysis with British and German establishment level data, European Journal of Industrial Relations 12, 165-188. 
[39] Soskice, D. (1990), Wage determination: The changing role of institutions in advanced industrialized countries, Oxford Review of Economic Policy 6, 36-61.

[40] Stephan, G. and K. Gerlach (2005), Wage settlements and wage setting: results from a multi-level model, Applied Economics 37, 2297-2306. 


\section{A Appendix}

\section{A.1 Construction of establishment variables:}

\begin{tabular}{ll}
\hline \hline Variable & Definition \\
\hline Establishment & Number of employees reported for the month June averaged \\
Per-capita & over the present and preceding year. \\
quasi-rents: & Quasi-rents are constructed by subtracting material costs and the alternative \\
& wagebill from annual sales. Per capita values are obtained by dividing \\
& quasi-rents by establishment size. Nominal values are deflated by a sector- \\
& specific (two-digit) producer price index. The alternative wagebill is defined \\
& as the annual wagebill which each firm would incur if it had to pay the \\
& average industrial wage. The average industrial wage per worker is \\
& approximated by the weighted average of industry-specific wages for blue \\
& and white-collar workers (separately for western and eastern Germany), \\
& with the weights being the establishment-specific shares of those \\
& worker groups in the total work force. \\
& Constructed by using the perpetual inventory method starting from the \\
& capital value in the first observation year and using the information on \\
& expansion investments. The initial capital value is proxied by dividing \\
& investment expenditures in each establishment's first observation year \\
bapital-labour a pre-period growth rate of investment, g, and a depreciation rate \\
ratio: \\
of capital, d.*) Capital-stocks in subsequent periods are calculated by \\
adding real expansion investment expenditures. Nominal investment \\
expenditures are deflated by the producer price index of investment goods \\
of the Federal Statistical Office Germany. The capital-labour ratio is con- \\
structed by dividing the resulting capital proxy by establishment size. \\
Dummy=1 if works council is present. In some waves (1995 and 1997) \\
only those plants who enter the panel are asked to report the existence \\
of a works council. For the remaining establishments the missing \\
information is imputed based upon the information in the following year. \\
$\begin{array}{l}\text { Dummy=1 if establishment is covered by a firm-specific agreement. } \\
\text { Dummy=1 if establishment is covered by an industry-specific agreement. }\end{array}$ \\
Works council:
\end{tabular}

Note: $\left.{ }^{*}\right)$ To calculate the capital stock in the first period, we set $\mathrm{d}=0.1$ and $\mathrm{g}=0.05$ (see also Guertzgen 2005).

Table A1: Description of establishment variables 


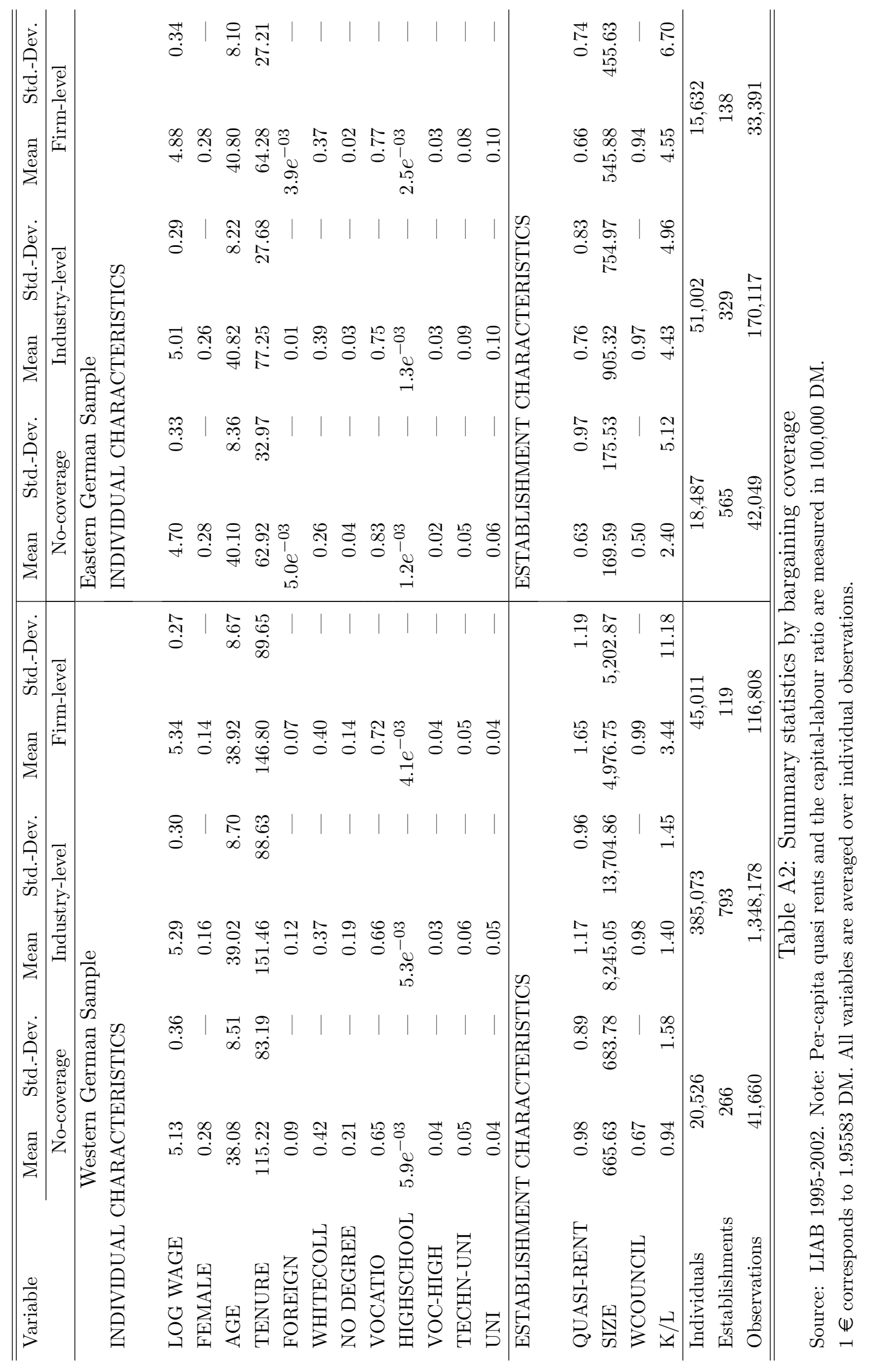




\begin{tabular}{|c|c|c|c|c|c|c|}
\hline & Mean & Std.-Dev. & Mean & Std.-Dev. & Mean & Std.-Dev. \\
\hline $\begin{array}{l}\text { Transition to } \\
\text { from }\end{array}$ & \multicolumn{2}{|c|}{ No-coverage } & \multicolumn{2}{|c|}{ Industry-level } & \multicolumn{2}{|c|}{ Firm-level contract } \\
\hline A. No-coverage & \multicolumn{2}{|c|}{$(\mathrm{J}=172)$} & \multicolumn{2}{|c|}{$(\mathrm{J}=40)$} & \multicolumn{2}{|c|}{$(\mathrm{J}=9)$} \\
\hline LOG WAGE & 5.03 & 0.25 & 4.93 & 0.33 & 5.12 & 0.20 \\
\hline FEMALE & 0.26 & - & 0.24 & - & 0.27 & - \\
\hline AGE & 38.22 & 3.50 & 37.43 & 5.44 & 36.73 & 4.66 \\
\hline TENURE & 102.69 & 47.42 & 104.45 & 62.66 & 95.81 & 49.91 \\
\hline FOREIGN & 0.07 & - & 0.04 & - & 0.06 & - \\
\hline WHITECOLL & 0.38 & - & 0.34 & - & 0.46 & - \\
\hline NO DEGREE & 0.17 & 一 & 0.13 & 一 & 0.14 & - \\
\hline VOCATIO & 0.71 & - & 0.80 & - & 0.77 & - \\
\hline HIGHSCHOOL & $4.3 e^{-03}$ & - & $1.9 e^{-03}$ & - & $2.9 e^{-03}$ & - \\
\hline VOC-HIGH & 0.04 & - & 0.01 & - & 0.04 & - \\
\hline TECHN-UNI & 0.03 & - & 0.05 & - & 0.03 & - \\
\hline UNI & 0.04 & - & 0.01 & - & 0.02 & - \\
\hline QUASI-RENT & 0.59 & 0.80 & 0.49 & 0.59 & 0.76 & 0.83 \\
\hline SIZE & 140.75 & 270.46 & 92.30 & 186.76 & 94.11 & 77.79 \\
\hline WCOUNCIL & 0.29 & - & 0.23 & - & 0.44 & - \\
\hline $\mathrm{K} / \mathrm{L}$ & 1.10 & 2.46 & 0.76 & 0.59 & 0.52 & 0.35 \\
\hline B. Industry-level & \multicolumn{2}{|c|}{$(\mathrm{J}=29)$} & \multicolumn{2}{|c|}{$(\mathrm{J}=688)$} & \multicolumn{2}{|c|}{$(\mathrm{J}=15)$} \\
\hline LOG WAGE & 5.02 & 0.27 & 5.16 & 0.22 & 5.14 & 0.23 \\
\hline FEMALE & 0.18 & - & 0.21 & - & 0.30 & - \\
\hline $\mathrm{AGE}$ & 36.69 & 4.61 & 39.06 & 2.82 & 37.41 & 5.18 \\
\hline TENURE & 96.25 & 47.42 & 127.64 & 48.14 & 97.69 & 68.59 \\
\hline FOREIGN & 0.10 & - & 0.09 & - & 0.07 & - \\
\hline WHITECOLL & 0.24 & - & 0.35 & - & 0.37 & - \\
\hline NO DEGREE & 0.23 & - & 0.21 & - & 0.22 & - \\
\hline VOCATIO & 0.73 & - & 0.69 & 一 & 0.71 & - \\
\hline HIGHSCHOOL & $1.3 e^{-03}$ & - & $5.55 e^{-03}$ & - & $2.1 e^{-03}$ & - \\
\hline VOC-HIGH & 0.02 & - & 0.03 & - & 0.01 & - \\
\hline TECHN-UNI & 0.01 & - & 0.04 & - & 0.03 & - \\
\hline UNI & 0.01 & - & 0.03 & - & 0.03 & - \\
\hline QUASI-RENT & 0.59 & 0.71 & 0.86 & 0.90 & 0.89 & 0.85 \\
\hline SIZE & 100.08 & 188.36 & 761,85 & 2,269.09 & 421.04 & 386.21 \\
\hline WCOUNCIL & 0.28 & - & 0.83 & - & 0.89 & - \\
\hline $\mathrm{K} / \mathrm{L}$ & 2.48 & 7.38 & 1.37 & 2.60 & 1.48 & 1.99 \\
\hline
\end{tabular}


.. continued

\begin{tabular}{lrrrrrr}
\hline \hline \multirow{2}{*}{$\begin{array}{l}\text { Transition to } \\
\text { from }\end{array}$} & \multicolumn{1}{c}{ Mean } & Std.-Dev. & \multicolumn{1}{c}{ Mean } & Std.-Dev. & \multicolumn{1}{c}{ Mean } & Std.-Dev. \\
\cline { 2 - 7 } No-coverage & \multicolumn{1}{c}{ Industry-level } & \multicolumn{2}{c}{ Firm-level contract } \\
C. Firm-level contract & \multicolumn{2}{c}{$(\mathrm{J}=16)$} & \multicolumn{2}{c}{$(\mathrm{J}=21)$} & \multicolumn{2}{c}{$(\mathrm{J}=58)$} \\
LOG WAGE & 5.01 & 0.28 & 5.08 & 0.22 & 5.20 & 0.21 \\
FEMALE & 0.36 & - & 0.22 & - & 0.19 & - \\
AGE & 39.68 & 4.13 & 37.81 & 2.49 & 38.55 & 2.56 \\
TENURE & 86.68 & 43.19 & 107.15 & 60.04 & 120.26 & 55.40 \\
FOREIGN & 0.03 & - & 0.05 & - & 0.07 & - \\
WHITECOLL & 0.47 & - & 0.31 & - & 0.38 & - \\
NO DEGREE & 0.15 & - & 0.14 & - & 0.17 & - \\
VOCATIO & 0.78 & - & 0.81 & - & 0.75 & - \\
HIGHSCHOOL & $6.2 e^{-03}$ & - & $7.3 e^{-04}$ & - & $6.2 e^{-03}$ & - \\
VOC-HIGH & 0.02 & - & 0.01 & - & 0.02 & - \\
TECHN-UNI & 0.03 & - & 0.02 & - & 0.03 & - \\
UNI & 0.02 & - & 0.02 & - & 0.03 & - \\
QUASI-RENT & 0.60 & 0.55 & 0.60 & 0.47 & 0.96 & 1.00 \\
SIZE & 135.98 & 176.32 & 188.77 & 287.27 & 991.91 & $2,257.63$ \\
WCOUNCIL & 0.25 & - & 0.71 & - & 0.90 & - \\
K/L & 0.74 & 0.57 & 1.48 & 2.65 & 8.36 & 43.27 \\
\hline \hline
\end{tabular}

Table A3: Summary statistics by transitions - West

Source: LIAB 1995-2002.

Note: Per-capita quasi rents and the capital-labour ratio are measured in 100,000 DM.

$1 €$ corresponds to $1.95583 \mathrm{DM}$. All variables are averaged over establishments. 


\begin{tabular}{|c|c|c|c|c|c|c|}
\hline & Mean & Std.-Dev. & Mean & Std.-Dev. & Mean & Std.-Dev. \\
\hline $\begin{array}{l}\text { Transition to } \\
\text { from }\end{array}$ & \multicolumn{2}{|c|}{ No-coverage } & \multicolumn{2}{|c|}{ Industry-level } & \multicolumn{2}{|c|}{ Firm-level contract } \\
\hline A. No-coverage & \multicolumn{2}{|c|}{$(\mathrm{J}=422)$} & \multicolumn{2}{|c|}{$(\mathrm{J}=31)$} & \multicolumn{2}{|c|}{$(\mathrm{J}=24)$} \\
\hline LOG WAGE & 4.56 & 0.25 & 4.66 & 0.26 & 4.60 & 0.22 \\
\hline FEMALE & 0.30 & - & 0.27 & - & 0.37 & - \\
\hline AGE & 39.12 & 5.07 & 39.03 & 6.60 & 41.01 & 5.31 \\
\hline TENURE & 61.84 & 24.42 & 70.42 & 24.67 & 66.85 & 24.87 \\
\hline FOREIGN & $4.2 e^{-03}$ & - & 0.01 & - & $4.7 e^{-03}$ & - \\
\hline WHITECOLL & 0.24 & 一 & 0.22 & - & 0.29 & - \\
\hline NO DEGREE & 0.03 & 一 & 0.01 & 一 & 0.10 & - \\
\hline VOCATIO & 0.87 & - & 0.85 & 一 & 0.81 & - \\
\hline HIGHSCHOOL & 0.00 & - & 0.00 & 一 & 0.00 & - \\
\hline VOC-HIGH & 0.03 & - & 0.02 & - & 0.02 & - \\
\hline TECHN-UNI & 0.03 & - & 0.10 & - & 0.03 & - \\
\hline UNI & 0.04 & - & 0.02 & - & 0.04 & - \\
\hline QUASI-RENT & 0.32 & 0.59 & 0.34 & 0.50 & 0.58 & 0.96 \\
\hline SIZE & 41.08 & 58.57 & 31.72 & 50.35 & 55.25 & 88.07 \\
\hline WCOUNCIL & 0.13 & - & 0.13 & - & 0.19 & - \\
\hline $\mathrm{K} / \mathrm{L}$ & 1.41 & 2.80 & 0.48 & 0.42 & 3.76 & 8.24 \\
\hline B. Industry-level & \multicolumn{2}{|c|}{$(\mathrm{J}=46)$} & \multicolumn{2}{|c|}{$(\mathrm{J}=224)$} & \multicolumn{2}{|c|}{$(\mathrm{J}=13)$} \\
\hline LOG WAGE & 4.58 & 0.26 & 4.88 & 0.24 & 4.74 & 0.37 \\
\hline FEMALE & 0.28 & - & 0.24 & - & 0.38 & - \\
\hline AGE & 38.34 & 5.39 & 39.76 & 3.19 & 40.33 & 2.06 \\
\hline TENURE & 65.04 & 23.80 & 72.25 & 20.27 & 64.69 & 19.71 \\
\hline FOREIGN & 0.00 & - & $5.3 e^{-03}$ & - & 0.02 & - \\
\hline WHITECOLL & 0.28 & - & 0.32 & 一 & 0.43 & - \\
\hline NO DEGREE & 0.00 & - & 0.05 & - & 0.03 & - \\
\hline VOCATIO & 0.92 & - & 0.79 & - & 0.82 & - \\
\hline HIGHSCHOOL & 0.00 & - & $1.7 e^{-03}$ & - & $1.2 e^{-03}$ & - \\
\hline VOC-HIGH & 0.01 & - & 0.02 & - & 0.02 & - \\
\hline TECHN-UNI & 0.04 & - & 0.07 & - & 0.06 & - \\
\hline UNI & 0.03 & - & 0.07 & - & 0.07 & 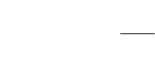 \\
\hline QUASI-RENT & 0.24 & 0.37 & 0.74 & 1.00 & 0.54 & 0.75 \\
\hline SIZE & 65.29 & 114.21 & 257.01 & 384.18 & 231.36 & 282.52 \\
\hline WCOUNCIL & 0.27 & - & 0.70 & - & 0.76 & - \\
\hline $\mathrm{K} / \mathrm{L}$ & 0.80 & 1.10 & 2.75 & 4.18 & 2.80 & 3.98 \\
\hline
\end{tabular}


.. continued

\begin{tabular}{|c|c|c|c|c|c|c|}
\hline \multirow[b]{2}{*}{$\begin{array}{l}\text { Transition to } \\
\text { from }\end{array}$} & Mean & Std.-Dev. & Mean & Std.-Dev. & Mean & Std.-Dev. \\
\hline & \multicolumn{2}{|c|}{ No-coverage } & \multicolumn{2}{|c|}{ Industry-level } & \multicolumn{2}{|c|}{ Firm-level contract } \\
\hline C. Firm-level contract & \multicolumn{2}{|c|}{$(\mathrm{J}=42)$} & \multicolumn{2}{|c|}{$(\mathrm{J}=15)$} & \multicolumn{2}{|c|}{$(\mathrm{J}=44)$} \\
\hline LOG WAGE & 4.65 & 0.24 & 4.82 & 0.30 & 4.73 & 0.24 \\
\hline FEMALE & 0.25 & - & 0.27 & - & 0.28 & - \\
\hline AGE & 39.43 & 4.46 & 37.36 & 6.48 & 40.72 & 2.52 \\
\hline TENURE & 59.11 & 23.97 & 56.25 & 22.47 & 60.64 & 16.87 \\
\hline FOREIGN & $3.2 e^{-03}$ & - & 0.03 & - & $3.1 e^{-03}$ & - \\
\hline WHITECOLL & 0.18 & - & 0.28 & - & 0.28 & - \\
\hline NO DEGREE & 0.04 & - & 0.01 & - & 0.03 & - \\
\hline VOCATIO & 0.89 & - & 0.87 & - & 0.83 & - \\
\hline HIGHSCHOOL & $1.6 e^{-03}$ & - & 0.00 & - & $2.8 e^{-03}$ & - \\
\hline VOC-HIGH & 0.02 & - & 0.02 & - & 0.02 & - \\
\hline TECHN-UNI & 0.02 & - & 0.05 & - & 0.06 & - \\
\hline UNI & 0.03 & - & 0.05 & - & 0.05 & - \\
\hline QUASI-RENT & 0.33 & 0.48 & 0.37 & 0.28 & 0.46 & 0.68 \\
\hline SIZE & 106.62 & 177.87 & 198.93 & 414.80 & 213.54 & 245.40 \\
\hline WCOUNCIL & 0.42 & - & 0.57 & - & 0.73 & - \\
\hline $\mathrm{K} / \mathrm{L}$ & 1.68 & 4.35 & 1.44 & 2.63 & 1.50 & 3.30 \\
\hline
\end{tabular}

Table A4: Summary statistics by transitions - East

Source: LIAB 1996-2002.

Note: Per-capita quasi rents and the capital-labour ratio are measured in 100,000 DM.

$1 €$ corresponds to $1.95583 \mathrm{DM}$. All variables are averaged over establishments. 